\title{
Review Article \\ Foliar Litter Decomposition: A Conceptual Model with Focus on Pine (Pinus) Litter-A Genus with Global Distribution
}

\author{
Björn Berg \\ Department of Forest Sciences, University of Helsinki, FIN-00014 Helsinki, Finland \\ Correspondence should be addressed to Björn Berg; bb0708212424@gmail.com
}

Received 17 November 2013; Accepted 12 December 2013; Published 27 April 2014

Academic Editors: J. Kaitera and S. F. Shamoun

Copyright (C) 2014 Björn Berg. This is an open access article distributed under the Creative Commons Attribution License, which permits unrestricted use, distribution, and reproduction in any medium, provided the original work is properly cited.

\begin{abstract}
The genus Pinus encompasses c 120 species and has a global distribution. Today we know more about the decomposition of pine needle litter than litter from any other genus. This paper presents a developed conceptual three-phase model for decomposition, based on pine needle litter, starting with newly shed litter and following the process until a humus-near stable residue. The paper focuses on the mass-loss dynamics and factors regulating the process in the early phase, the late one, and the humus-near phase. For the late phase, the hampering influence of $\mathrm{N}$ and the rate-enhancing effect of $\mathrm{Mn}$ on the decomposition are given extra attention. Empirical factors related to the limit value/stable residue are discussed as well as the decomposition patterns and functions for calculating limit values. The climate-related litter concentrations of $\mathrm{N}$ and $\mathrm{Mn}$ are discussed as well as their possible influence on the size of the stable residue, which may accumulate and sequester carbon, for example, in humus layers. The sequestration of carbon in humus layers is discussed as well as the effect of tree species on the process. Although the paper focuses on litter of pine species, there are comparisons to studies on other litter genera and similarities and differences are discussed.
\end{abstract}

\section{Introduction}

The process "plant litter decomposition" is quantitatively as large as the photosynthesis. The process is necessary for the recirculation of nutrients and a continued buildup of plant biomass as well as for the maintenance of food webs through the energy released by the degradation of organic compounds.

The main process which we, a bit simplified, call "plant litter decomposition" is extremely complex and can be subdivided into a multitude of subprocesses. These include not only release of nutrients but also a stepwise degradation of the main chemical compounds present in the shed litter. Also, synthesis processes are included in the concept, resulting in new compounds, which in turn may recombine, often creating a recalcitrance of the remaining litter mass. In spite of its importance, this system of subprocesses is mainly unknown.

The concept "plant litter" is wide both regarding components and their chemical composition and foliar litter appears to be the litter fraction that has been most studied. Still, with foliar litter of different species having very different chemical composition (e.g., DELILA III data base; http://www.eko.uj.edu.pl/deco/) we may expect different decomposition patterns among species or at least among genera. Also, bark, twig, branch, root, and foliar litter from the same plant may have different chemical composition and thus follow different decomposition patterns.

To create a first comprehensive image of the decomposition process as such, we may need to create at least a conceptual model, ideally based on one litter species or one genus. Such a model should include influences of litter nutrients and organic components as well as rate-regulating factors and the litter's contribution to accumulation of soil organic carbon. To do this we need to formulate basic questions about the process, simple questions that are reflecting what we need to know.

An example; for a long time there was a generally accepted assumption that litter decomposed completely and thus decomposition rates were considered to be not only of high interest but also a main parameter as discussed by Prescott [1]. However, questions based on such assumptions were of less value as it has shown that rates may range from a high one for newly shed litter to close to zero at a later stage, 
well before the litter is completely decomposed. At present, we may describe such changes in rate in just general terms and for just a few species.

By tradition, there appears to be a general opinion and image that climate rules decomposition on a regional scale, whereas litter chemical composition dominates the process on a local one. The picture may be more complicated, though, and is not entirely correct. Meentemeyer [2] and later Berg et al. [3] and Kang et al. [4] demonstrated a large-scale effect of climate on decomposition rate of newly shed plant litter. However, such an effect is not general to all litter species [5, 6] and not to all decomposition stages [7], but the changed substrate composition may dominate decomposition ratesat least for some foliar litter species.

The influence of the substrate on the decomposition process may thus be such that the proposed climate change and a suggested raise in temperature may be without influence on the mineralization rate of soil organic matter (SOM). Such a substrate influence is due to the changed chemical composition during decomposition. What may cause the increasing recalcitrance of partly decomposed litter and the decrease in decomposition rate is today not clear, although the well-established decrease in rate has been related to concentration of gravimetric lignin in litter (Acid Unhydrolyzable Residue-AUR). This relationship was observed by Fogel and Cromack [8] and later developed $[2,7]$ to different climate situations. However, new analytical techniques have made it clear that the concept AUR may be complex and appears to encompass native lignin, waxes, tannins, cutins, as well as newly synthesized compounds $[9,10]$.

A subdivision of AUR into different components may be of help to distinguish what compounds that accumulate in litter and what factors that influence their degradation. We cannot exclude that the developing ${ }^{13} \mathrm{C}$-NMR technique may change the concept of native lignin as a recalcitrant compound.

In most Nordic/boreal coniferous forests, the number of soil animals is low [11], which means that the decomposition is mainly microbial and more than $90 \%$ is carried out by microorganisms. The dominant microbial degradation may facilitate the interpretation of decomposition data as well as the application of microbial mechanisms to the decomposition process. Further, the lack of burrowing soil animals creates intact humus layers, which facilitates the determination of carbon (C) sequestration.

A help parameter for decomposition studies was found by Howard and Howard [12] as they estimated a level of the accumulated mass loss with the decomposition rate zero, which later has been called a "limit value" for decomposition. They used a function giving an asymptote. Their study was confirmed by Wieder and Lang [13] who introduced a more handable function (Equation 3; Section 3.3.4). Later the concept was developed $[14,15]$, including the suggestion of a negative influence of nitrogen $(\mathrm{N})$ concentration on the limit value. The pattern described by (3) means that the accumulated mass loss approaches a limit value, which can be described by an asymptotic function.
So far such limit values have been described mainly for litter in forest systems in boreal and temperate areas and recently also for subtropical and tropical ones $[16,17]$. Litter at this stage may be assumed to be close to $\mathrm{SOM}$ as discussed by Berg et al. [18], who used litter $\mathrm{N}$ concentration as an internal marker.

Limit values for 106 sets of 21 species of decomposing foliar litter from natural forest systems were estimated [19], using litters representing a wide range in chemical composition. A highly significant negative relationship between limit values and initial litter $\mathrm{N}$ concentrations was found [19]. Limit values for pine (Pinus) species have also been positively related to initial concentrations of manganese $(\mathrm{Mn})[20,21]$.

With the massive information in the data base from the Long-term Intersite Decomposition Experiment Team (LIDET) confirming that decomposing foliar litter leaves a stable residue $[16,17]$ we may expect that the focus of interest for decomposition studies may change to be more directed towards (i) explaining the retardation of the decomposition process, (ii) developing the concept limit value that defines the stable fraction, and (iii) explaining the stability of the residue. Hopefully, future studies will be more directed towards single species or genera as was suggested in a recent synthesis paper [22].

That long-term humus buildup and storage are possible was shown by Wardle et al. [23] when they determined such a buildup to have taken place for close to 3000 years. The buildup was reconstructed quantitatively [24] using foliar litter fall and the remaining stable fraction. Such a buildup is not uncommon and the property of humus-layer depth has been presented as a dominant property of a humus form "Tangelhumus" [25]. This humus form, with up to c. $1 \mathrm{~m}$ deep humus layers, has been described for the Alps and for mountains in Central Europe.

The reconstruction of humus layers has been extended to encompass the sequestration of $\mathrm{N}[26,27]$. The approach of using limit values seemed to make it possible to quantify the remaining, recalcitrant mass in the very late stages and may allow a further evaluation. Such a relative stability may be important for the sequestration of carbon dioxide $\left(\mathrm{CO}_{2}\right)$ in humus. As regards the long-term stability of humus, the information is scarce and to some extent contradictory. Thus, Berg and Matzner [28] report that increasing $\mathrm{N}$ concentrations in humus decrease the decomposition rate. That report was based on a study of Bringmark and Bringmark [29] covering a gradient along Sweden. In contrast, there are reports on extremely active humus disintegration that may be related to humus N concentrations [30].

The aim of this paper is to review and organize existing knowledge of the decomposition of foliar litter with focus on pine species (Pinus) needle litter. The information will be organized into a structure to create a system of influencing factors on the decomposition process starting with newly shed litter and following it to SOM and C sequestration. To this purpose, I have reviewed existing information on Scots pine (Pinus sylvestris) needle litter and other pine species. A reason to this choice is that we seem to have more information about pine needle litter and its decomposition than of any other litter species or genus. Further, with c. 105 to 125 
TABLE 1: Some abbreviations, acronyms, and specific terms used in this paper.

\begin{tabular}{ll}
\hline Acronym & Meaning \\
\hline MAT & Mean annual temperature $\left({ }^{\circ} \mathrm{C}\right)$ \\
MAP & Mean annual precipitation $(\mathrm{mm})$ \\
AET & Annual actual evapotranspiration (mm) acc. to [2] \\
PET & Potential evapotranspiration (mm) acc. to [2] \\
& Acid Unhydrolyzable Residue or gravimetric lignin \\
& (refers to different methods, e.g., sulfuric acid \\
AUR & lignin, Effland lignin, acid detergent lignin). See; \\
& for example, $[9,10]$. \\
\hline
\end{tabular}

identified pine species, now with global distribution and occurring in boreal, temperate, and subtropical forests, we appear to have a model substrate, decomposing in several environments, and climate situations. Pine litter already has been suggested as a reasonable model substrate [22]. Throughout the paper, I will focus on the components N, Mn, AUR, and native lignin. As far as we know today, these are key components in the decomposition process, not excluding that further factors may be identified.

Further, I discuss (i) what parameters that may be of importance for a characterization of a given decomposition pattern, (ii) if the presented conceptual model may be of use for further genera of foliar litter, and (iii) if developing analytical tools may change basic findings about the decomposition process.

Data and information is taken from the literature with focus on foliar litter of Scots pine and other pine species. I repeatedly quote the DELILA database (DELILA II and DELILA III; http://www.eko.uj.edu.pl/deco/).

\section{Terminology}

Abbreviations, acronyms, and specific terms are collected in Table 1 and in part explained below.

Accumulated Mass Loss. The total amount of litter mass lost from a decomposing litter substrate, normally expressed as a percentage of initial mass.

AUR (Acid Unhydrolyzable Residue) refers to gravimetric lignin such as sulfuric-acid lignin and Effland lignin.

Decomposition Pattern refers to the general development of accumulated litter mass loss with time. Often the decomposition rate slows down and ceases, with the consequence that the accumulated mass loss does not increase. At the rate zero, we may estimate a "limit value" with a so far known range from c. 42 to $100 \%$. See also [21].

Holocellulose. A term covering cellulose plus hemicelluloses, and thus the polymer carbohydrates in litter.

Limit Value is the calculated value for the extent of decomposition of a given litter type, at which the decomposition rate approaches zero.Limit value may be given as accumulated mass loss (\%) or as a fraction. It may also be calculated, using remaining amount and then given as percentage remaining amount.

\section{Discussion}

\subsection{The Chemical Composition of Pinus Foliar Litter with Focus on Nutrients and AUR}

\subsubsection{Organic-Chemical Composition}

Some Comments. There is limited information on organic compounds in foliar litter. Cellulose, hemicellulose, and AUR are the quantitatively dominant ones (Tables 2 and 3) with a variation in proportions between annual litter falls and among species. The developing ${ }^{13} \mathrm{C}$-NMR technique has given us a tool that may open new possibilities to work on plant litter, although so far this technique gives the quantity of specific bonds, rather than compounds and we will discuss both the new method and the more traditional ones.

Several studies on chemical composition have been made using extractions of hemicellulose and cellulose based on solubility in alkaline solutions (e.g., acid detergent lignin) and although useful, they are not included in this review as they are less specific.

Traditional Techniques. Available detailed data on organic components in foliar litter is old today and few studies have been carried out, which separates the specific components [31]. Separating solid substance and different soluble fractions, the authors identified 44 organic compounds in Scots pine needle litter.

We may see that there is not much variation in the main compounds among the investigated five litter species (Table 2), still there is a certain variation in soluble substances and AUR. Some variations in proportions of hemicelluloses and cellulose have been observed with glucans and mannans having higher concentrations in the three coniferous species. In contrast, silver birch (Betula pendula) has higher levels of xylans and rhamnans.

As regards AUR, Johansson et al. [7] found a concentration that ranges from 223 to $288 \mathrm{mg} \mathrm{g}^{-1}$ when analyzing newly shed Scots pine needle litter collected in the same stand over 17 consecutive years. Although the concept AUR is not very specific and includes native lignin, waxes, cutins, and tannins $[9,10]$, it still deserves to be discussed as it has been widely used as an index of recalcitrance for litter. Available data [34] shows a range in AUR between $234 \mathrm{mg} \mathrm{g}^{-1}$ in Chir pine (Pinus roxburghii) and Scots pine to 432 in Khesi pine.

An empirical, general, and positive relationship has been found between concentrations of AUR and $\mathrm{N}$ in pine needle litter (Figure 1) as well as for specific groups like coniferous and broadleaf litter species [39]. A similar observation was made in $\mathrm{N}$ fertilization experiments for Scots pine and Norway spruce (Picea abies) [32, 40, 41].

${ }^{13} \mathrm{C}-\mathrm{NMR}$ Technique. New analytical techniques, such as ${ }^{13} \mathrm{C}$ $\mathrm{NMR}$, may in part replace the traditional, time consuming ones and provide new information. So far ${ }^{13} \mathrm{C}-\mathrm{NMR}$ rather 
TABLE 2: Initial composition of organic-chemical components and nutrients in five litter species. Data from [14, 31-33].

\begin{tabular}{|c|c|c|c|c|c|c|c|c|c|}
\hline & \multicolumn{9}{|c|}{ Concentrations of components $\left(\mathrm{mg} \mathrm{g}^{-1}\right)$} \\
\hline & \multicolumn{2}{|c|}{ Substances soluble in } & \multirow{2}{*}{ AUR } & \multicolumn{6}{|c|}{ Relative proportions of carbohydrates } \\
\hline & Water & Ethanol & & Rhamnan & Xylan & Galactan & Mannan & Araban & Glucans \\
\hline Scots pine & 164 & 113 & 231 & 3 & 23 & 32 & 75 & 36 & 245 \\
\hline Scots pine ${ }^{1}$ & 92 & 120 & 240 & 1 & 23 & 30 & 64 & 43 & 214 \\
\hline Lodgepole pine & 103 & 42 & 381 & 6 & 34 & 46 & 90 & 48 & 254 \\
\hline Norway spruce & 32 & 48 & 318 & 7 & 33 & 28 & 105 & 40 & 288 \\
\hline Silver birch & 241 & 57 & 330 & 16 & 77 & 44 & 14 & 49 & 166 \\
\hline Grey alder & 254 & 39 & 264 & 9 & 30 & 32 & 10 & 44 & 116 \\
\hline
\end{tabular}

${ }^{1}$ Recalculated from [31].

TABle 3: Concentrations of seven main nutrients and AUR in foliar litter of a few pine species. Available data. From [34].

\begin{tabular}{|c|c|c|c|c|c|c|c|c|c|}
\hline \multirow{2}{*}{ Litter sp. } & \multicolumn{9}{|c|}{ Concentration $\left(\mathrm{mg} \mathrm{g}^{-1}\right)$} \\
\hline & $\mathrm{N}$ & $\mathrm{P}$ & $\mathrm{S}$ & $\mathrm{K}$ & $\mathrm{Ca}$ & $\mathrm{Mg}$ & $\mathrm{Mn}$ & AUR & Lit. ref. \\
\hline Scots pine $^{\mathrm{a}}$ & 4.2 & 0.23 & 0.44 & 0.79 & 5.3 & 0.45 & 1.03 & 249 & [7] \\
\hline Lodgepole pine & 3.9 & 0.34 & 0.62 & 0.56 & 6.4 & 0.95 & 1.79 & 360 & {$[15]$} \\
\hline Maritime pine & 6.8 & 0.54 & 1.01 & 1.95 & 3.1 & 1.90 & 0.59 & 326 & $*$ \\
\hline Red pine & 6.0 & 0.36 & 0.73 & 1.40 & 8.9 & 2.00 & 0.73 & 265 & $* *$ \\
\hline White pine & 5.9 & 0.21 & 0.68 & 0.70 & 7.2 & 1.10 & 0.80 & 256 & $* *$ \\
\hline Jack pine & 7.8 & 0.64 & 0.77 & 2.30 & 4.0 & 2.10 & 0.25 & 329 & $* *$ \\
\hline Limber pine & 4.3 & 0.43 & 0.52 & 1.10 & 5.3 & 1.10 & 0.21 & 258 & $* *$ \\
\hline Ponderosa pine & 5.5 & 0.45 & 0.56 & 1.5 & 3.8 & 1.22 & 0.20 & 294 & $* *$ \\
\hline Stone pine & 3.0 & 0.57 & 1.36 & 5.9 & 7.1 & 2.4 & 0.19 & 312 & {$[35]$} \\
\hline Corsican pine & 4.7 & 0.54 & 0.71 & 3.5 & 7.8 & 1.3 & 0.50 & 276 & $* *$ \\
\hline Monterey pine & 5.6 & 0.22 & 0.70 & 1.3 & 1.9 & 0.93 & 0.47 & 406 & $* *$ \\
\hline Aleppo pine & 4.3 & 0.38 & 1.3 & 1.73 & 25.2 & 2.33 & 0.03 & 341 & {$[58]$} \\
\hline Virginia pine & 6.5 & 0.76 & 1.37 & 1.8 & 5.1 & 1.05 & 1.48 & 347 & $* *$ \\
\hline Black pine & 6.1 & 0.35 & 1.12 & 0.8 & 10.6 & 1.6 & 0.86 & 280 & {$[43]$} \\
\hline Chir pine & 6.7 & nd & nd & nd & nd & nd & nd & 234 & [49] \\
\hline Khasi pine & 9.8 & nd & nd & nd & nd & nd & nd & 432 & [49] \\
\hline
\end{tabular}

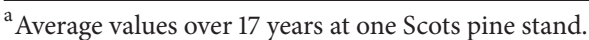

${ }^{*}$ DELILA III data base (http://www.eko.uj.edu.pl/deco).

** B. Berg and C. McClaugherty (unpubl.).

gives information about specific bonds than compounds, which may open up for new interpretations of data. At the present development stage, however, the concentration of a chemical compound is given as that of a certain C-bond. A bond is identified as the response in a certain frequency interval and we may expect such responses to be complex [10] (Table 4).

Some recent papers $[10,42,43]$ have reported initial chemical composition of whole litter (Table 4). We may see rather wide ranges in response signals among species. For example, a range factor of more than 4 for Methoxy-C, a factor of c. 2 for Aromatic-C, and Phenolic-C and c. 3 for Carbonyl-C. Among the three pine species, there was a variation too, but smaller. These studies encompassed whole litter, thus including extractives.

Alkyl-C or Aliphatic-C. This frequency interval (0$50 \mathrm{ppm}$ ) indicates long chains with $-\mathrm{CH}_{2}$-units. A side chain in hemicellulose, namely, an acetate group belongs here as well as $\mathrm{C}$ in side chains of lignin. Available data (Table 4) gives a clear variation among litter species (from 15.7 to 25.8\%).
Methoxy-C (50-60 ppm) shows the methoxyl carbon in lignin. However, this frequency interval also includes the alkyl carbon bound to $\mathrm{N}$ in proteins. A clear variation is seen, ranging from 1.5 to $6.61 \%$.

O-Alkyl-C (60-93 ppm) encompasses mainly carbohydrate carbon, namely, that in cellulose and hemicelluloses, but also the side chains of lignin going from carbon 3. Further, some signals from tannins come in this interval.

Di-O-Alkyl-C (93-112 ppm) mainly encompasses cellulose plus hemicelluloses, and thus carbohydrate carbon but shows no difference between the different carbohydrates. We may see (Table 4) that the highest frequencies are found for O-Alkyl-C, followed by Di-O-Alkyl-C, which mainly reflect cellulose plus hemicellulose. These appear to be highest for Scots pine and beech. The intensity for O-Alkyl-C ranges from 39.4 for black spruce (Picea mariana) to 61.4 for black pine (Pinus nigra) litter.

Aromatic-C or Aryl-C. The intensity in this interval (112$140 \mathrm{ppm}$ ) comes from the aromatic carbon in both lignin and condensed tannins. It may also show the guaiacyl group of lignin. 
TABLE 4: Relative contribution (\% of total area) of different groups of C-bonds as derived from ${ }^{13} \mathrm{C}$ CP-NMR spectra of newly shed foliar litter.

\begin{tabular}{|c|c|c|c|c|c|c|c|c|}
\hline Litter species & $\begin{array}{c}\text { Alkyl-C } \\
0-50\end{array}$ & $\begin{array}{c}\text { Methoxy-C } \\
50-60\end{array}$ & $\begin{array}{c}\text { O-alkyl-C } \\
60-93\end{array}$ & $\begin{array}{c}\text { Di-O-alkyl-C } \\
93-112\end{array}$ & $\begin{array}{c}\text { Aromatic-C } \\
112-140\end{array}$ & $\begin{array}{c}\text { Phenolic-C } \\
140-165\end{array}$ & $\begin{array}{c}\text { Carbonyl-C } \\
165-190\end{array}$ & Lit. ref. \\
\hline Scots pine & 15.8 & 5.28 & 50.9 & 12.5 & 7.32 & 5.82 & 2.39 & {$[42]$} \\
\hline Scots pine & 16.4 & 5.46 & 51.4 & 12.4 & 6.80 & 5.35 & 2.20 & {$[42]$} \\
\hline Jack pine & 23.4 & 2.2 & 44.8 & 10.5 & 8.6 & 5.9 & 4.6 & {$[10]$} \\
\hline Black pine $^{\mathrm{a}}$ & 16.1 & 5.0 & 61.4 & - & - & 5.0 & 3.6 & {$[43]$} \\
\hline Norway spruce & 17.2 & 6.21 & 44.9 & 11.6 & 9.65 & 7.30 & 3.13 & {$[42]$} \\
\hline Black spruce & 20.5 & 4.4 & 39.4 & 9.9 & 12.4 & 6.7 & 6.7 & {$[10]$} \\
\hline Douglas fir & 23.2 & 1.5 & 45.2 & 8.7 & 9.4 & 6.4 & 5.5 & {$[10]$} \\
\hline Tamarack & 15.9 & 1.7 & 43.3 & 16.5 & 8.0 & 11.1 & 3.5 & {$[10]$} \\
\hline White birch & 25.8 & 2.4 & 43.7 & 11.7 & 7.1 & 6.3 & 2.9 & {$[10]$} \\
\hline Silver birch & 23.0 & 5.58 & 43.6 & 12.1 & 6.13 & 5.56 & 3.98 & {$[42]$} \\
\hline Aspen & 22.8 & 1.5 & 39.4 & 12.2 & 7.3 & 7.5 & 6.6 & {$[10]$} \\
\hline Beech & 15.7 & 3.2 & 48.7 & 11.9 & 9.6 & 6.0 & 5.0 & {$[10]$} \\
\hline
\end{tabular}

${ }^{\mathrm{a}}$ The investigated intervals were somewhat different.

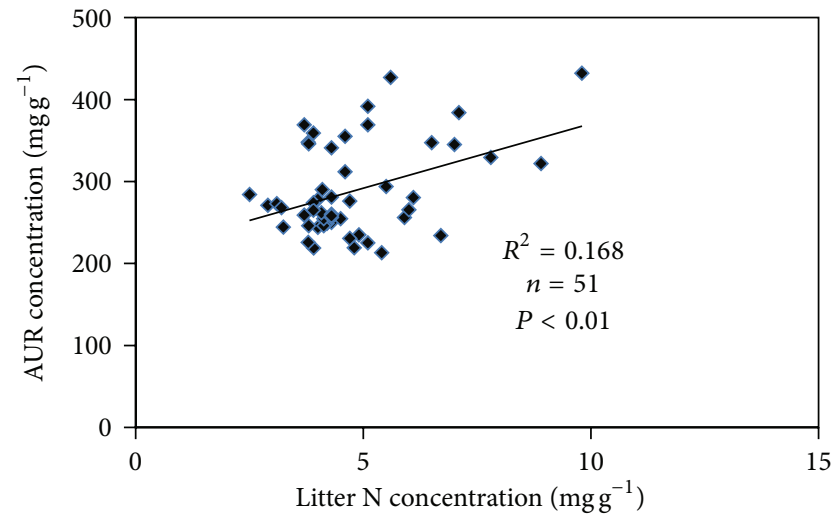

FIGURE 1: A positive relationship between $\mathrm{N}$ and AUR concentrations in needle litter of 51 samples of 10 pine (Pinus) species. Data from [39] and the DELILA database; http://www.eko.uj.edu.pl/deco/.

Phenolic-C. The intensity in this interval comes from phenolic C (140-165 ppm) in both lignin and condensed tannins. It may also show the syringyl group of lignin. Aromatic- $\mathrm{C}$ and Phenolic-C, reflecting aromatic carbon show a clear variation among litter species, with a range from 12.4 for black spruce to 6.13 for silver birch litter. Phenolic-C ranged from 11.1 for tamarack (Larix laricina) to 5.0 for black pine.

Carboxyl-C or Carbonyl-C (165-190 ppm). This region includes carboxylic acids, amides and esters. The intensity for Carbonyl-C ranged from 6.7 for black spruce to 2.2 for Scots pine.

So far relatively few studies have been carried out, which limits the possibilities to draw conclusions.

\subsubsection{Two Main Nutrients and Heavy Metals}

What Factors Influence Litter Concentrations of $N$ and $M n$ ? It appears that concentrations of nutrients in pine litter and several other genera vary along at least three axes, one being species/genus, another climate, and a third one soil properties at the site of growth. We cannot exclude that these are linked and when a given species is dependent on both climate and soil properties, both influence the litter chemistry simultaneously.

Pine Species-Available Data. Newly shed needle litter has been analyzed for just a few pine species and the analyses are rather incomplete, encompassing mainly the seven main nutrients. In general, the nutrient levels are low, for example, for $\mathrm{N}$, with a range from 3.0 to a highest value of 9.8 for Khesi pine (Table 3). Pines normally grow on nutrient-poor soil, which in part may explain this generally low level.

The natural variation over 17 years at one stand of Scots pine ranged from 2.9 to $4.8 \mathrm{mg} \mathrm{g}^{-1}$ [7] with an occasional $10.4 \mathrm{mg} \mathrm{g}^{-1}$ possibly due to an interruption in the retranslocation process. Still, occasionally high $\mathrm{N}$ levels $\left(23.0 \mathrm{mg} \mathrm{g}^{-1}\right)$ have been observed, for example, for black pine [43], when the trees grew in a system supporting the dinitrogen-fixing Mount Etna broom (Genista aetnensis).

The variation among species/genera increases when we leave the genus Pinus. So far there has not been any systematic grouping of genera/species versus nutrient concentrations, so what nutrients such a variation encompasses, in addition to $\mathrm{N}$, is not possible to say. The large global approach of Kang et al. [33] indicates a difficulty already for $\mathrm{N}$ and $\mathrm{P}$. Although $\mathrm{N}$ and $\mathrm{P}$ are mainly correlated, there were differences both in concentrations and the N-to-P ratio among continents and main functional groups. An alternative approach is that of Tyler [47] using no less than 58 macro- and micronutrients as well as rare earth metals, possibly over a limited area.

Variation with Climate. The chemical composition of the newly shed pine litter varies considerably with climate. In 1995, Berg et al. [48] reported positive relationships between $\mathrm{N}, \mathrm{P}, \mathrm{S}$, and $\mathrm{K}$ and the climate indices MAT and AET. They used mainly Scots pine needle litter but also those of 7 further pine species, collected over Western Europe. Later, a positive relationship was reported between $\mathrm{N}$ and MAT for eight species of pine litter $(n=56)$ in a gradient from the Equator 


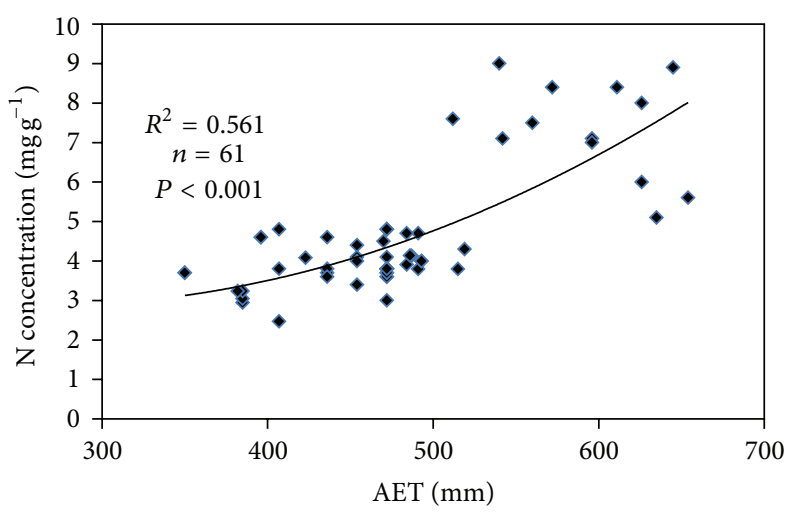

(a)

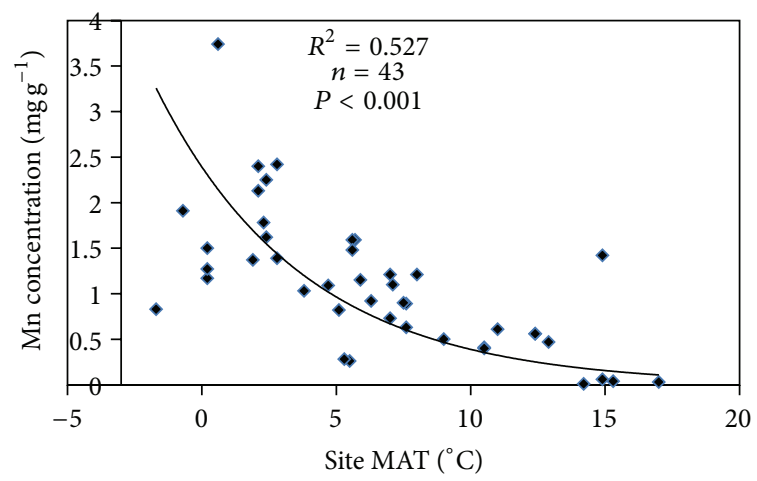

(b)

FIGURE 2: All available data for newly shed pine (Pinus) needle litter in a climatic gradient ranging from northernmost Fennoscandia to south Spain and south Italy. Nitrogen and Mn were analyzed on the same litter samples. (a); increasing N concentration with increasing site AET (b); decreasing Mn concentration with increasing site MAT. Data from [21, 48], and the DELILA database; http://www.eko.uj.edu.pl/deco/.

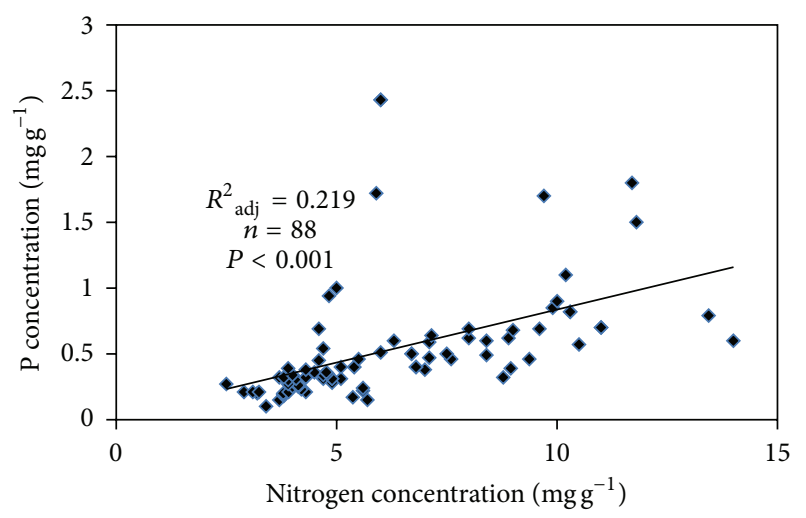

FIGURE 3: Relationship between concentrations of $\mathrm{N}$ and $\mathrm{P}$ in pine (Pinus) species needle litter, collected in stands over Europe, Asia, and North America. The data encompasses 22 pine species. B. Berg, unpublished. Data from $[7,48]$ and the DELILA database; http://www.eko.uj.edu.pl/deco/.

in Southeast Asia to the Arctic Circle in Scandinavia with a MAT range from 0 to $28^{\circ} \mathrm{C}$ [49]. Using standardized data, they could confirm that MAT $(P<0.001)$ and not MAP gave a highly significant relationship. We may see (Figure 2) that the available data for pine needle litter gives a highly significant relationship $\left(R^{2}=0.561 ; n=61 ; P<0.001\right)$ to AET.

That the main nutrients are related not only to climate factors but to each other may be seen over the climate gradient as discussed by Berg et al. [48]. An example is that of $\mathrm{N}$ and $\mathrm{P}$. For 22 pine species $(n=88)$ in the northern hemisphere, the concentrations of $\mathrm{N}$ and $\mathrm{P}$ are well correlated (Figure 3). The variation may be due to the different species or environmental factors, possibly MAT. For one species, namely, Scots pine with 38 samples, the correlation was considerably better $\left(R_{\mathrm{adj}}^{2}=0.830 ; P<0.001\right)$ as compared to $R_{\text {adj }}^{2}=0.219(P<0.001)$ for the 22 different species (Figure 3). This emphasizes that also for litter, the concept species is important. This kind of relationship ( $\mathrm{N}$ versus $\mathrm{P}$ ) has been confirmed on a global level for several litter species [33].

A further nutrient that may be related to climate indices is $\mathrm{Mn}$. Negative relationships between Mn concentrations and AET/MAT have been reported for pine litter [21, 48] (Figure 2(b)). We may see that there is a highly significant negative relationship to MAT for eight pine species $(n=43)$ covering the area from northernmost Scandinavia to North Africa.

The relationship between Mn concentration and MAT was clearly stronger than that to AET. Both relationships were negative, indicating that the higher the average temperature, the lower was the Mn concentration in the litter. The highest Mn levels were found in Scots pine in north Scandinavia $\left(3.67 \mathrm{mg} \mathrm{g}^{-1}\right)$ and the lowest $\left(0.03 \mathrm{mg} \mathrm{g}^{-1}\right)$ in Aleppo pine (Pinus halepensis) in North Africa (Figure 2(b)). This relationship is still empirical.

With the relationship for $\mathrm{N}$ being positive to MAT and that for Mn being negative, there was a negative relationship between $\mathrm{N}$ and $\mathrm{Mn}$ in the pine needle litter with $R^{2}=0.145$; $n=42 ; P<0.05$ (Figure 4). Thus, with increasing MAT (AET), there is an increasing N-to-Mn quotient in the litter. The concentrations of these two nutrients, important for lignin degradation thus vary strongly over a climatic gradient with a range in MAT from -1.7 to $17^{\circ} \mathrm{C}$ and a geographical range of $4200 \mathrm{~km}$.

A certain variation among species, possibly due to place of growth or deviating site conditions may be seen for $\mathrm{Ca}$ and $\mathrm{Mg}$ (Table 3). In their analyses, Berg et al. [48] found no relationship to climate factors for $\mathrm{Ca}$ and $\mathrm{Mg}$ and concluded that soil factors were ruling their concentrations in litter.

3.1.3. A Covariation in AUR and Nitrogen Concentrations in Newly Shed Litter. There appears to be a positive relationship between concentrations of $\mathrm{N}$ and AUR in foliar litter for 


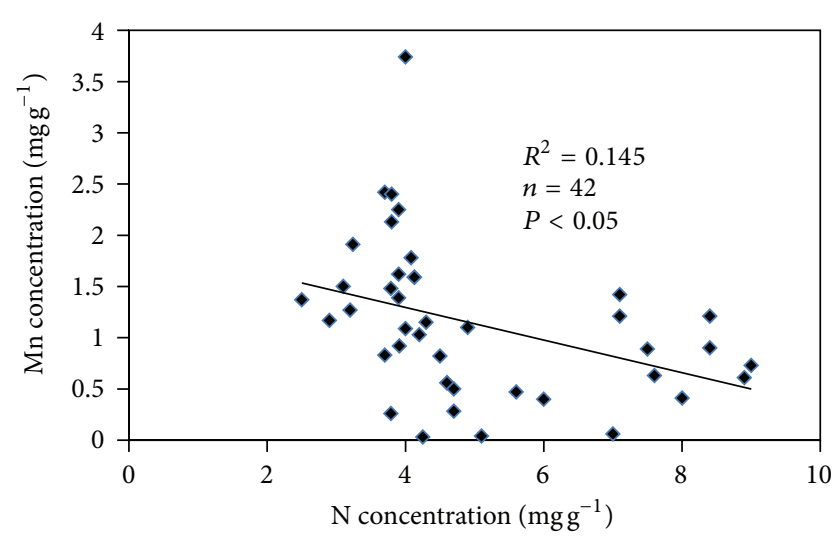

FIgUre 4: Within the genus Pinus there appears to be a negative relationship between concentrations of $\mathrm{N}$ and $\mathrm{Mn}$ in newly shed needle litter along a climate gradient ranging from 1.7 to $17^{\circ} \mathrm{C}$. B. Berg unpublished. Data from [48] and the DELILA database; http://www.eko.uj.edu.pl/deco/.

both coniferous and broadleaf litter (both at $P<0.0001$ ) as well as for pine needle litter [39] (Figure 1). The latter relationship was based on 10 pine species $(n=51)$ with $P<$ 0.01 . This relationship is empirical and we cannot exclude that it will be subdivided as AUR will be, using ${ }^{13} \mathrm{C}-\mathrm{NMR}$. It may be mentioned that after $\mathrm{N}$ fertilization, both Scots pine and Norway spruce shed needle litter with increased AUR concentrations $[40,41]$. The concentration of AUR also has been shown to vary with climate. Thus, Berg et al. [48] reported positive relationships between AUR in pine needle litter and both MAT and potential evapotranspiration (PET). Also this relationship is empirical.

3.1.4. Relative Amounts of $\mathrm{N}$ and $\mathrm{Mn}$ in Litter Fall. The relative composition of foliar litter fall for pine species changes with MAT and AET as does the amount of litter fall. Thus, litter fall is positively related to AET and in northern Europe also to MAT, where temperature rather than precipitation is limiting [50]. This was seen also by Liu et al. [51] for pine litter over Eurasia.

As the concentration of $\mathrm{N}$ in needle litter fall increases with, for example, MAT and AET, the amounts of $\mathrm{N}$ that are returned to the soil in litter fall are predictable and there is a heavy increase with increasing AET.

For $\mathrm{Mn}$, the situation is less clear but largely the concentration decreases with MAT and AET. Still, there is a high variation in concentration among years and sites which makes the amounts less predictable. We may, however, estimate proportions between $\mathrm{N}$ and $\mathrm{Mn}$ for a few cases. Using real data for pine needle litter gives for a stand with a MAT of $0^{\circ} \mathrm{C}$ an N-to-Mn ratio of 2.5 , at a MAT of $10^{\circ} \mathrm{C}$ the ratio becomes 25.6 , and at a MAT of $17^{\circ} \mathrm{C}$ it becomes 133 . Thus, the relative amount of $\mathrm{N}$ increases considerably with MAT as compared to that of $\mathrm{Mn}$.

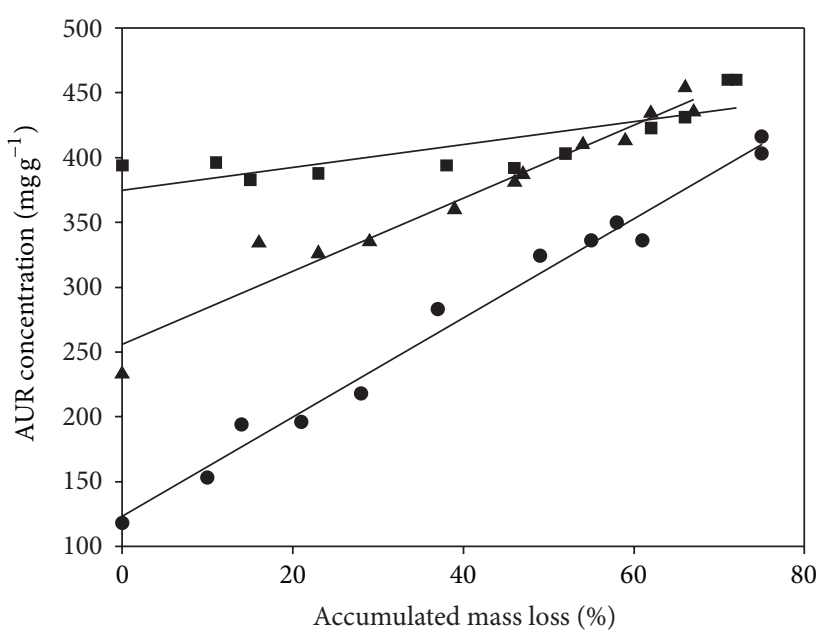

FIGURE 5: During decomposition, the concentration of AUR increases. The AUR concentration may be plotted versus accumulated litter mass loss. By doing that, we obtain a linear relationship, which is readily comparable for litter incubated in different climate zones and among different litter species. Scots pine (-), lodgepole pine $(\boldsymbol{\square})$, Norway spruce $(\boldsymbol{\Delta})$. Data from $[31,52,53]$, figure from [32].

\subsection{The Long-Term Decomposition Process}

\subsubsection{How Do Concentrations and Amounts of Solubles, Holo-} cellulose, AUR, and Native Lignin Develop with Accumulated Mass Loss?

Long-Term Development of Some Main Processes. Some litter species allow us to follow the decomposition process until rather high values of accumulated mass loss or until the decomposition process appears to go very slowly. Several studies using pine needle litter have recorded values for accumulated mass loss of $80 \%$ and above. Such mass losses may be reached in shorter or longer periods, to some extent depending on climate. We discuss the concept long term with reference to accumulated mass loss.

The concept long term is not directly related to the three identified stages [28] (below). The three stages were introduced to describe some main steps in litter degradation, namely, what components and factors that dominate and in part regulate the decomposition rate. The stages may also help to distinguish what nutrients that are limiting the decomposition in the different steps.

In the course of decomposition, when the more easily degradable compounds are decomposed, AUR remains relatively intact for a long time and the amount may even increase. This means that the litter becomes enriched in AUR, its concentration increases and may reach even above 50\% (Figure 5).

The AUR analysis gives normally a clear increase in concentration and is a useful index for litter recalcitrance. However, in decomposing litter, AUR integrates the most hydrolysis-resistant organic structures and is an analytical fraction derived from lignin, condensed tannins, cutins, and 
waxes [10]. As an index of litter recalcitrance and age it may be useful. However, we must call it an empirical index.

Soluble Substances. Foliar litter may contain considerable levels of soluble substances. For example, concentrations of water-solubles ranging between $7 \%$ in Scots pine needles [7] and 30\% in grey alder (Alnus incana) leaves have been reported [14]. So far, four principal groups of soluble organic material in pine needle litter have been identified, namely, sugars, phenolics, hydrocarbons, and glycerides. The soluble sugars are predominantly mono- and oligosaccharides that were involved in metabolic processes of the plant. The soluble phenolics are low-molecular weight compounds that serve either as defensive agents against herbivory, are lignin precursors, or waste products; hydrolysable tannins are a common example of soluble phenolics. Phenolics are highly variable in their solubility and many have a tendency to condense into less soluble forms or to react with larger molecules.

Part of these substances may be leached out of the litter $[54,55]$ and part may be degraded in the litter structure. Few attempts have been made to follow the degradation of simple soluble components in litter and it should be pointed out that most studies describe net disappearance only. The soluble fraction is challenging to study, due to the complexities of tracing the formation of new solubles during decomposition and the disappearance of the same solubles due to leaching or metabolism.

Compounds such as triglycerides and hydrocarbons that are soluble in light petroleum ether may disappear quickly, whereas fatty acids and diterpene acids remain for longer periods. Simple sugars, for example, glucose and fructose, or compounds related to simple sugars such as glycosides and pinitol, are also degraded very early and at a high rate [31]. Still, as an example, glucose, which is present initially in newly shed litter is also produced from decomposing cellulose and is thus found even in the later stages of decomposition. The same applies to the simple sugars of hemicelluloses. Also several phenolic substances that are found in newly shed litter are produced, but later during the degradation of, for example, native lignin.

Solubles are mainly studied as compounds soluble in water and ethanol/acetone and generally the water soluble fraction is quickly decomposed, and consequently it decreases in concentration. This has been generally observed for the few litter species that have been studied in some detail. The ethanol/acetone soluble fraction, which contains phenolics and higher fatty acids may remain more constant or even increase in concentration although there appears to be a clear variation among litter species.

Cellulose and Hemicelluloses. Based on traditional analytical techniques [31,32], the components cellulose, hemicelluloses, and AUR have been shown to be degraded at different ratesin the early stages of decomposition. Still, throughout the decomposition process, there are no drastic changes in the concentration of cellulose. Berg et al. [31] found for Scots pine needle litter a slight increase followed by a decrease to about the initial concentration. For pine litter, part of the cellulose is lignified when the needle litter is newly shed and part is not. This may be common among litters although it has been little investigated. Some litters such as Norway spruce needle litter and that of common oak (Quercus robur) appear to have very little, if any cellulose that is not lignified.

The most common hemicelluloses decompose in a similar fashion in litter. For the most part, they behave like cellulose, although they may have different positions in the decomposing fiber tissue. The concentrations of, for example, xylans, mannans, arabinans, and galactans with smaller variations remain about constant as far as the decomposition process has been followed. Considering the structure and complexity of the hemicelluloses, we may simplify our discussion and regard them as a group. When considered together, we may see that in Scots pine needle litter their concentration at 70\% accumulated mass loss is about the same as at the start of the incubation [31]. Like cellulose, hemicelluloses appear to be in part lignified and in part not.

Using a long-term incubation of needle litter of Japanese cedar (Cryptomeria japonica) and Hinoki cypress (Chamaecyparis obtusa), Ono et al. [56] showed an initially fast loss of Alkyl-C and O-Alkyl-C bonds corresponding to carbohydrates. It appears that the decomposition rates for O-Alkyl-C were higher in the first incubation year. They compared the rates to those of Aromatic- $\mathrm{C}$ representing lignin and Carbonyl-C (below).

"Lignin" Is Often Determined as Acid Unhydrolyzable Residue (AUR). Native lignin is not a very clear concept either in fresh or decomposing litter and so far lignin has been defined on the basis of proximate (gravimetric) analytical methods rather than purely chemical criteria. When applied on newly shed litter, some proximate methods yield results which may be close to chemically defined lignin. However, in decomposing plant litter, lignin is modified by the humification processes, including condensation reactions, and by partial degradation by microorganisms. The formation of such decay products, which are included in the AUR fraction, may raise arguments about the extent to which true lignin is measured in decomposing litter when analyzed as AUR. In addition, gravimetric lignin (AUR) will contain, among other compounds, cutin, waxes, and tannins [10]. Further, an inorganic fraction (ash) can be of considerable magnitude. Although the latter fraction for, for example, Scots pine litter is about $1 \%$ of the total litter mass, it may amount to some percent in the gravimetric lignin analysis. The ash content of newly shed deciduous litter can be much higher, going above $10 \%$ in some cases [57]. Furthermore, ash concentrations may increase during decay and should be considered when reporting AUR contents of decomposing litter. In an extreme case [36], fine particles of mineral soil were found to penetrate the litter and "ash" increased from 5.3 to $15.6 \%$.

There are some clear differences between AUR and NMRdetermined lignin, which need to be clarified. Although what is determined as AUR is not true lignin but a mixed chemical fraction with compounds, some of which have similarities to true lignin. It is important to note that even native lignin is highly variable among and even within species. Thus, native 
TABLE 5: Mean intensity distributions (\% of total area) as well as mean ratio Alkyl-to-O-Alkyl. Data, which originates from [10] give ratios for $75 \mathrm{MHz}{ }^{13} \mathrm{C} C P$ NMR of spectra of newly-shed litter and after 2 and 6 years of decomposition. Mean values refer to 10 foliage litter.

\begin{tabular}{lcccccccc}
\hline \multirow{2}{*}{ Litter species } & Alkyl-C & Methoxy-C & O-Alkyl-C & Di-O-Alkyl-C & Aromatic-C & Phenolic-C & Carbonyl-C & Alkyl/O-Alkyl \\
& $0-47$ & $47-58$ & $58-92$ & $92-112$ & $112-140$ & $140-160$ & $160-185$ & 0.32 \\
\hline Mean newly shed & 18.9 & 4.5 & 42.3 & 12.3 & 9.8 & 6.6 & 5.6 & 7.6 \\
Mean 2 years & 23.0 & 5.5 & 36.6 & 10.0 & 10.9 & 6.5 & 0.45 \\
Mean 6 years & 22.2 & 6.6 & 33.7 & 10.1 & 12.4 & 6.9 & 8.1 & 0.44 \\
\hline
\end{tabular}

lignin cannot be described with the same chemical precision as cellulose or other plant polymers.

Lignin is not a well-defined compound when it is produced and it remains a poorly defined compound as it is decomposing. The nomenclature for lignin that has been modified during decomposition is still in question and even misleading terms like "Acid-Insoluble Substance" are seen in the literature. One suggestion is "Non-Hydrolyzed Remains" (NHR) [58]. The more recent suggestion "Acid Unhydrolyzable Residue" (AUR) [10] appears to have won a more general acceptance.

It should be pointed out that although the terminology sometimes is misleading, the gravimetric lignin or AUR that contains chemically recalcitrant matter, is still today an important concept to litter decomposition. It has turned out that AUR also represents a biologically recalcitrant unit. Although we also need methods to identify native lignin as well as to identify the compounds included in AUR, we may still use AUR as an index for degradability [34].

Two approaches have been made to describe the change in concentrations of cellulose and hemicellulose versus that of AUR. In the long term, the concentration of holocellulose decreases, whereas that of AUR increases, and as observed, there is a level at which the relative amounts remain constant. Berg et al. [59] suggested the term holocellulose-to-lignin quotient (HLQ). Two such quotients are as follows:

$$
\text { HLQ }=\frac{\text { holocellulose }}{(\text { AUR }+ \text { holocellulose })}
$$

(see [59]). Another was suggested by Melillo et al. [60] as follows:

$$
\mathrm{LCI}=\frac{\mathrm{AUR}}{(\mathrm{AUR}+\text { holocellulose })} .
$$

The upper relationship [59] approaches a minimum value asymptotically, which may be different for different litter types. For example, Berg et al. [59] found a clear difference between the HLQ values for Scots pine and silver birch indicating a difference in the quality of the carbon source.

The purpose of the two approaches was to obtain a quality measure for the litter carbon source. With a new analytical tool, namely, the ${ }^{13} \mathrm{C}-\mathrm{NMR}$, we cannot exclude that the indices will be more useful.

True Lignin. The old concept that lignin concentration increases during decomposition has been efficiently questioned $[10,61]$. We cannot exclude that an increase may be different among litters and depend on the main degrading organism (e.g., white rot versus brown rot). According to some papers, it thus appears that concentrations of native lignin itself do not increase during the decomposition process, but rather the sum of components that may be recalcitrant as seen when analyzing for AUR (e.g., sulfuricacid lignin). On the other hand, Ono et al. [56] found an increase in concentrations of Aromatic-C when following the decomposition dynamics over four years of Japanese cedar needle litter and that of Hinoki cypress. Considering the faster loss of O-Alkyl-C and Alkyl-C such an increase is reasonable. We cannot exclude that contradictory reports reflect a difference in composition of decomposing organisms (e.g., white rot versus brown rot).

When using ${ }^{13} \mathrm{C}-\mathrm{NMR}$ analysis, bonds such as Methoxy$\mathrm{C}$, Aromatic- $\mathrm{C}$, and Phenolic- $\mathrm{C}$ may indicate the concentration of lignin. Aromatic-C and Phenolic-C are also found in condensed tannins [10]. In their CIDET study, Preston et al. [10] reported intensity spectra for decomposition of 10 foliar litter species with measurements at 0,2 , and 6 years (Table 5 ). For Aromatic-C and Phenolic-C, there were clear increases in concentration.

Considering the discussion in the above papers [10, 61], we cannot exclude that in a near future it will be possible to distinguish litter decomposition by white rot versus that by brown rot and their relative participation in lignin degradation.

\subsubsection{Dynamics of Two Main Nutrients: $N$ and $M n$}

Some Comments. In decomposition studies just total concentrations of nutrients are normally used. The information value of total concentrations is limited for evident reasons and does not tell us how these nutrients are bound in litter and the decomposing material, nor what fraction that is available. Some nutrients are in part bound with covalent bonds to organic molecules and thus belong to organic complexes, and some of those in ion form are readily leachable, for example, potassium (K). Thus, N, P, and S are bound in proteins and the nucleic acids that remain in the litter when shed. During decomposition also the developing microbial biomass needs the $\mathrm{N}, \mathrm{P}$, and $\mathrm{S}$ for building proteins and nucleic acids and when following their total concentrations with accumulated mass loss, we may see that their concentrations increase in linear proportion. Their concentrations need to be in proportion in the microbial biomass and this has been noted especially for the relationship between $\mathrm{N}$ and $\mathrm{P}$ which has been well studied [62].

Nitrogen dynamics appears to have been more studied than that of other nutrients and there are several synthesis 


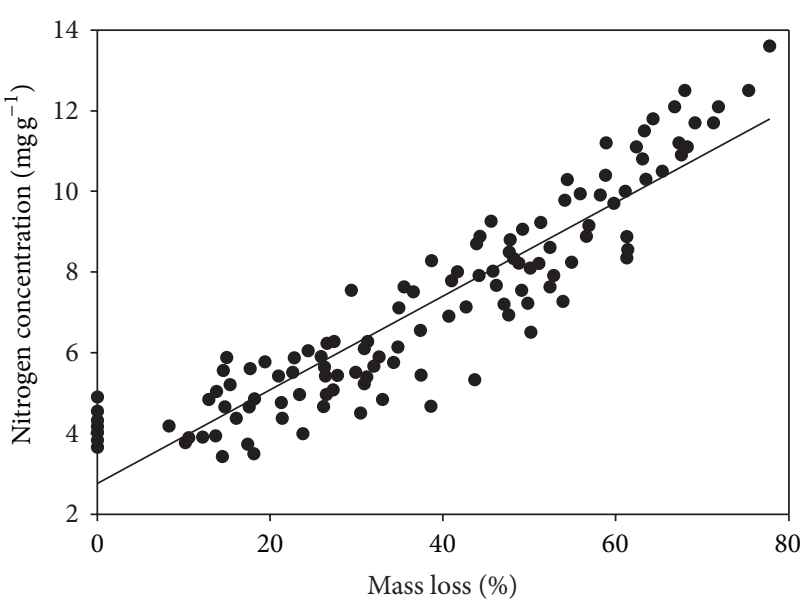

FIGURE 6: Linear relationship between increasing concentrations of $\mathrm{N}$ and accumulated mass loss for decomposing Scots pine needle litter. Incubations were made at one site, a nutrient-poor Scots pine forest. Data are pooled from 14 studies, each representing an incubation of local litter sampled in a different year $\left(R^{2}=0.843\right.$; $n=131 ; P<0.001)$. Figure from [32], data from $[44,67]$.

works $[63,64]$. Basic syntheses may also be found in textbooks $[65,66]$.

The discussion below is limited to the main nutrients $\mathrm{N}$ and $\mathrm{Mn}$, which have been found to be important for the longterm decomposition of litter. Heavy metals in natural and clean environments have been suggested to be important for regulating decomposition at the very late stages $[9,34]$. Still, the literature on, for example, $\mathrm{Fe}, \mathrm{Pb}, \mathrm{Zn}$, and $\mathrm{Cu}$ dynamics is very limited.

Nitrogen Concentrations Increase as Decomposition Proceeds. That concentrations of total $\mathrm{N}$ increase in decomposing litter is well known. Berg and McClaugherty [32] related the increasing $\mathrm{N}$ concentrations to litter accumulated mass loss for several litter types, resulting in a linear increase $[32,44,67]$ (Figure 6), possibly until the limit value for decomposition is reached [18]. This type of relationship is useful and may be used for analytical purposes. Such a linear increase has been found for many species including foliar litter of pine species, Norway spruce as well as for broadleaf litters $[67,69]$.

For one Scots pine stand, there was a limited variability among decomposition studies (Figure 6). The litter was naturally produced from a Scots pine monocultural system, and the variation in initial $\mathrm{N}$ concentration was the observed annual variation. Similar comparisons were made for needle litter of lodgepole pine and Norway spruce litter with rather little variation. The increase in $\mathrm{N}$ concentration during decomposition may be considerable. Thus, for Scots pine, a linear increase was found in concentration from an initial $4 \mathrm{mg} \mathrm{g}^{-1}$ up to 12 to $13 \mathrm{mg} \mathrm{g}^{-1} \mathrm{~N}$ at about $75 \%$ accumulated mass loss $\left(R^{2}=0.99 ; n=16 ; P<0.001\right)$ [70].

Some deciduous litter species, such as silver birch, also give linear relationships, although much of the mass is lost initially, resulting in a fast increase in $\mathrm{N}$ relative to mass

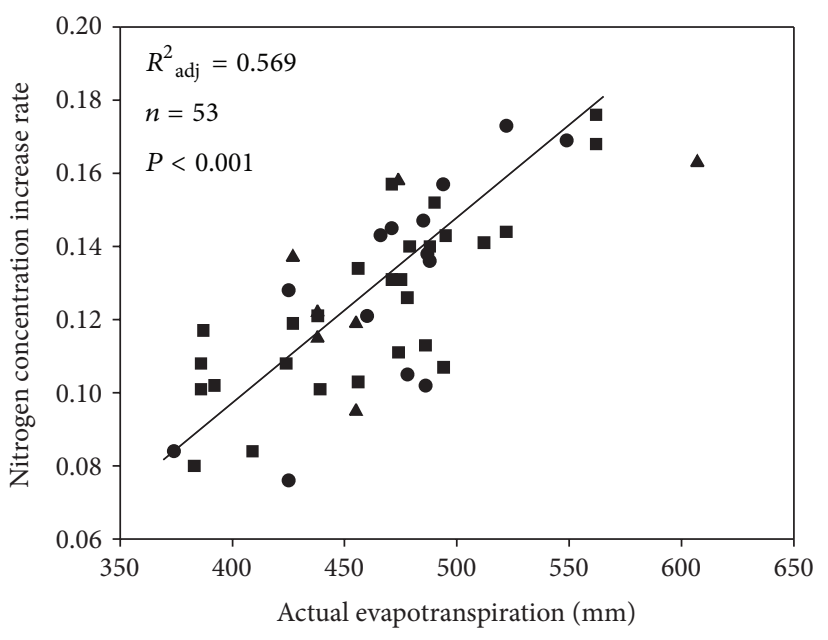

Figure 7: Linear relationship between the climatic index actual evapotranspiration (AET) and Nitrogen Concentration Increase Rate (NCIR) for decomposing needle litter of $(\bullet)$ Scots pine, ( $\mathbf{\square})$ Norway spruce, and $(\boldsymbol{\Delta})$ other pines (lodgepole pine and white pine). Figure from [32], data from [67].

loss. This linearity is empirical and the reasons for the linear relationship are far from clear, given the simultaneous in- and outflows of $\mathrm{N}$ during the decomposition process $[66,71]$. This relationship has also been elaborated [18, 67].

Some Influences on N Dynamics May Be Systematized. Using the linear relationship between $\mathrm{N}$ concentration and accumulated mass loss, Berg and McClaugherty $[32,34]$ compared the slopes of the linear relationships among several litter species and among several studies of decomposing Scots pine needle litter in one forest system (Figure 7). They called the slope of the relationship Nitrogen Concentration Increase Rate (NCIR). An advantage with linear relationships is that they may be readily and simply compared and Berg and McClaugherty [32, 34] found a set of factors influencing the NCIR. One factor appeared to be litter species, another was the influence of initial litter $\mathrm{N}$ concentrations, and a third the influence of climate. Thus, the NCIR increased with increasing initial $\mathrm{N}$ concentration, a property which appeared to be in common for different species. They found this to be valid for at least a few pine species and for Norway spruce. Berg and Cortina [69] also noticed this when comparing NCIR for seven very different litter types incubated in one system.

One mechanism for conserving $\mathrm{N}$ in decomposing litter could be via covalent bonds to macromolecules during the humification process. A first step is the ammonium fixation described by Nömmik and Vahtras [72]. When the initial amount of $\mathrm{N}$ in the litter is higher, there will be more $\mathrm{N}$ available for fixation, giving a higher NCIR. Such a conclusion is reasonable since Axelsson and Berg [73] found that the $\mathrm{N}$ availability is limiting the rate of the process.

Earlier studies suggested that quinones were formed with $\mathrm{N}$ in the heterocyclic rings [74]. Two recent papers give further compounds [45, 75]. The study of Knicker [75] 
<smiles>Cc1cc(C)c2c(C)c[nH]c2c1</smiles><smiles>Cc1[nH]c(C)c(C)c1C</smiles><smiles>[R]C(N)=O</smiles>

Amide<smiles>Cc1c(O)c(C)c(O)c(N)c1O</smiles>

Aminohydroquinone<smiles>Cc1nc(C)c(C)c(C)c1C</smiles>

Pyridine<smiles>Cc1c(C)c(C)c(C#N)c(C)c1C</smiles>

Benzonitrile

FIGURE 8: Products detected by ${ }^{15} \mathrm{~N}-\mathrm{NMR}$ after reaction of ${ }^{15} \mathrm{~N}$ labeled ammonium hydroxide with humic material after oxidative ammonolysis of lignin model compounds. Figure from [75].

suggested several heterocyclic components (Figure 8), which may be part of the recalcitrant complexes formed.

Influence of climate on NCIR. For local Scots pine needle litter and a unified Scots pine needle litter preparation, the relationship between NCIR and AET was investigated across a climatic gradient, with AET ranging from 380 to $520 \mathrm{~mm}$. There was a highly significant positive relationship $\left(R_{\text {adj }}^{2}=0.640 ; n=31 ; P<0.001\right)$ indicating that the $\mathrm{N}$ concentration will increase faster relative to accumulated mass loss under a warmer and wetter climate. This correlation was significant when local and unified needle litters were used in combination as well as when using only local needle litter $\left(R_{\mathrm{adj}}^{2}=0.517 ; n=18 ; P<0.001\right)$. Also, for litter of Norway spruce, the NCIR values increased with increasing AET values and the relationship was well significant $\left(R_{\text {adj }}^{2}=0.534\right.$; $n=14 ; P<0.01)$. Combining data for brown coniferous litter resulted in a highly significant linear relationship with $R_{\text {adj }}^{2}=$ $0.569 ; n=53 ; P<0.001$ (Figure 7).

Thus, climate as indexed by AET is a significant factor in affecting the rate of $\mathrm{N}$ concentration increase in decomposing leaf litter. As the increases were calculated on the basis of accumulated mass loss rather than time, the results mean that, at a given accumulated mass loss, a particular litter decaying in an area with higher AET will contain more $\mathrm{N}$ than the same litter decaying in an area with lower AET.

Manganese Concentrations Change with Accumulated Mass Loss. There are few reviews and/or syntheses on Mn dynamics in decomposing litter. As seen from a comparison of Scots pine and Norway spruce needle litter, the former has not only lower Mn concentration in newly shed litter but there is also a clear difference in Mn dynamics during decomposition. Berg et al. [76] compared the two genera in two approaches, (i) by using information from 8 paired stands with Scots pine and Norway spruce and (ii) by using available data for $\mathrm{Mn}$ dynamics for 3 pine species and Norway spruce. They used 63 decomposition studies in which Mn was analysed in each litter sampling (546 data points) and related concentrations and remaining amounts of $\mathrm{Mn}$ in litter to accumulated mass loss.

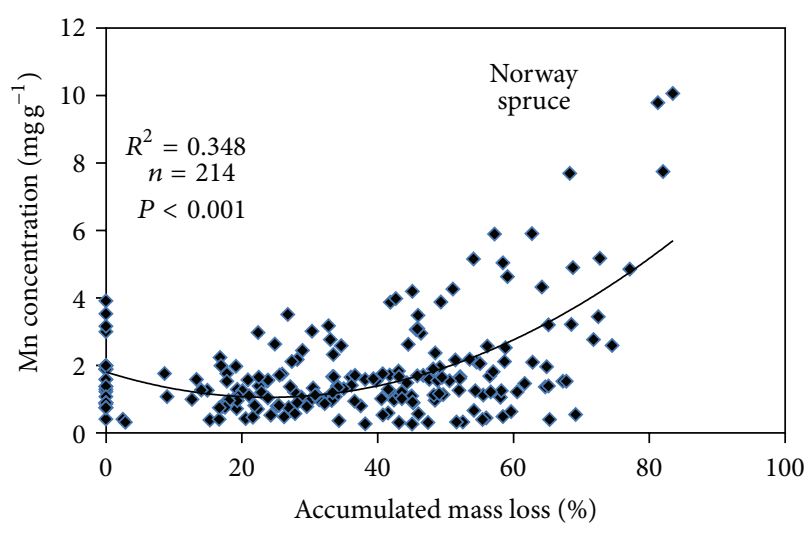

(a)

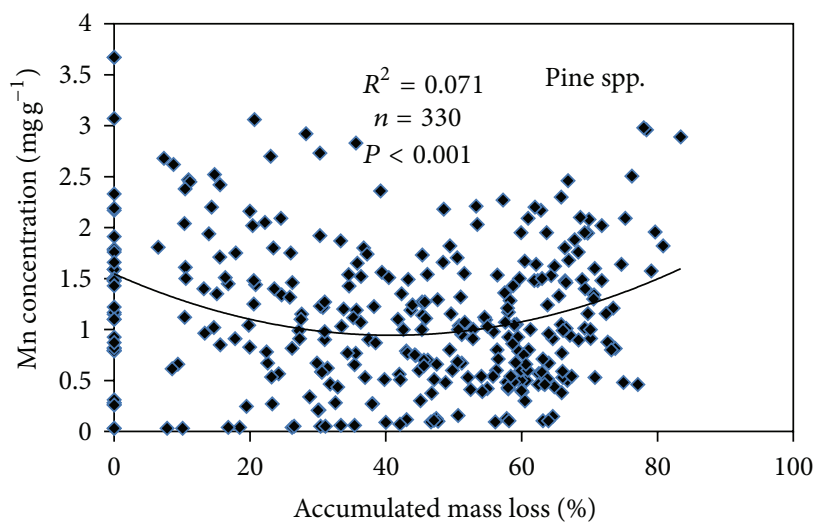

(b)

FIGURE 9: Manganese concentration in decomposing needle litter of Norway spruce (a), Scots pine, lodgepole pine, and Aleppo pine (b). Data originates from a climatic gradient. A quadratic function of the type $X^{2}-X$ fitted both data sets reasonably well. Data from $[58,69,76]$. Please note the different scales on the $Y$ axis.

For both the pine (37 studies) and the spruce litter (26 studies), the pattern for Mn concentration with accumulated mass loss varied among the single studies. The variation may depend on initial concentration, ranging from an increase at low initial concentrations to a clear decrease at high initial levels.

For both litters, a high initial Mn concentration resulted in a decrease in concentration as decomposition proceeded. Mainly it appeared that the concentration decreased and at c. $15-20 \%$ accumulated mass loss Mn concentrations reached a minimum after which the concentrations increased following accumulated litter mass loss (Figure 9).

Scots Pine versus Norway Spruce in Paired Stands as well as Available Data for Pine spp. and Norway Spruce. In their synthesis, Berg et al. [76] investigated how litter Mn concentration changed with accumulated mass loss in 8 paired stands with Norway spruce and Scots pine (pairwise the same soil and the same climate). The resulting patterns showed a clear difference between them with a not very clear pattern for Scots pine (cf. Figure 9). As decomposition proceeded, the Mn concentration reached a minimum, followed by a slight 
increase, which was significant, but not very pronounced. In contrast, the Norway spruce litter showed a very clear and strong increase in concentration, which was significantly stronger than for litter of Scots pine $(P<0.0001)$. For each group of litter, Mn concentration followed a significant positive quadratic function $\left(X^{2}-X\right)$. The average $\mathrm{Mn}$ concentration at $80 \%$ accumulated mass loss was $6.26 \mathrm{mg} \mathrm{g}^{-1}$ for Norway spruce litter and $1.47 \mathrm{mg} \mathrm{g}^{-1}$ for that of Scots pine. The quotient in Mn concentration at $80 \%$ mass loss between Norway spruce and Scots pine was 4.3.

In the same study, they combined all available data for pine species and Norway spruce and the pattern (Figure 9) was similar to that for the paired stands. Pine litter did not give a very clear pattern for changes in concentration and at $60-70 \%$ accumulated mass loss, the range in concentrations was about as wide as for the newly shed litter. A quadratic function was highly significant $\left(R^{2}=0.070 ; n=330 ; P<\right.$ 0.001 ) but indicated a very low increase in concentration. For Norway spruce litter, on the other hand, there was a clear increase in concentration (Figure 9) and significantly higher than for pine species.

Manganese Release Patterns during Decomposition. Manganese release from litter was generally linear to accumulated mass loss. This was investigated for 63 decomposition studies encompassing Scots pine, lodgepole pine, Aleppo pine, and Norway spruce, and found to be linear for each individual study [76]. This linearity was used for comparing the Mn release rates for some litters with different initial concentrations.

The slope of such a linear relationship gives the release rate, and the slopes for the 63 relationships were related to litter initial $\mathrm{Mn}$ concentration. It appeared that the release rate was in proportion to the litters' initial concentration of $\operatorname{Mn}(P<0.001)$ and this relationship was highly significant in spite of the different genera. Although the species groups fitted a common function, there were significant differences among them. Thus, the functions for the groups Norway spruce and pine species were significantly different $(P<$ 0.001); [76] with a clearly lower release rate for Mn in Norway spruce litter (Figure 10).

\subsection{A Conceptual Model Based on Three Identified Stages}

\subsubsection{Some Introductory Comments}

Two Phases Have Developed to Three. Based on traditional analytical techniques, Berg and Staaf [40] set up a conceptual two-phase model for decomposition of Scots pine needle litter and included $\mathrm{N}$ as a rate-retarding factor for AUR decomposition in the late stage. Later, the model was developed to encompass three identifiable stages [28]. In addition to $\mathrm{N}$, this modified model included $\mathrm{Mn}$ as an influencing factor for the late stage.

The early phase was based on the decomposition of nonlignified carbohydrates and mass-loss rate was enhanced by higher levels of the main nutrients N, P, and S. Further, in this phase, there was a direct effect of climate on decomposition. The late phase started when a net loss of AUR was observed

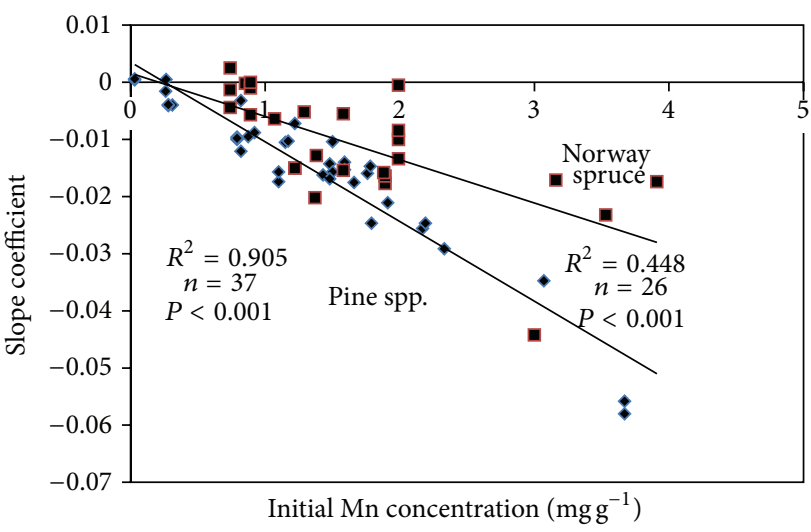

Figure 10: Net release/uptake in foliar litter of pine species and Norway spruce using Mn release coefficients for linear functions. Available data for pine species was used $(n=37)$ as well as for Norway spruce $(n=26)$. The resulting linear function for pine and spruce litter combined was highly significant $\left(R^{2}=0.635 ; n=63 ; P<\right.$ 0.001 ). The figure shows that the data set could be subdivided after genus with the two functions significantly different at $P<0.001$. Pine species $(\diamond)$, Norway spruce $(\square)$. Data recalculated from [76].

and in contrast to the early phase, a raised $\mathrm{N}$ concentration would have a rate-suppressing effect, whereas a higher $\mathrm{Mn}$ concentration would increase the litter mass-loss rate. The effect of climate would decrease and possibly disappear. The third stage or humus-near stage, [28] was defined by the limit value, which identified a stable litter fraction.

Both new data and additional analytical work on lignin in litter [61] have made it necessary to clarify and develop the definition of the phases, considering the new information [34].

In a new approach, Hobbie et al. [77] followed the development of enzymatic activities during decomposition of leaf litter of white pine (Pinus strobus) and pin oak (Quercus ellipsoidalis) providing further support to the model. A further study [78] encompassed flowering dogwood (Cornus florida), red maple (Acer rubrum), and red oak (Quercus rubra). Also, in this case, studies on enzyme activities supported the model.

\subsubsection{Early Stage: What Factors May Regulate the Decomposition Rate?}

Substrate Chemical Composition. In the early phase, amounts and concentrations of water-soluble substances decrease quickly before reaching relatively similar and stable levels [31]. Also, free unshielded holocellulose is degraded in this phase. In the first work, based on AUR, no net loss of AUR was seen in the early phase. Recently, Klotzbücher et al. have found [61] that also in the early phase, there is some lignin degradation (cf. Figure 11). Their data set included Scots pine needle litter. Still, although there is some degradation of lignin, this appears not to influence the effects of the main nutrients and the degradation of carbohydrates appears to dominate the early phase.

The recent finding of Klotzbücher et al. [61] has shown that part of the native lignin thus may be degraded in 


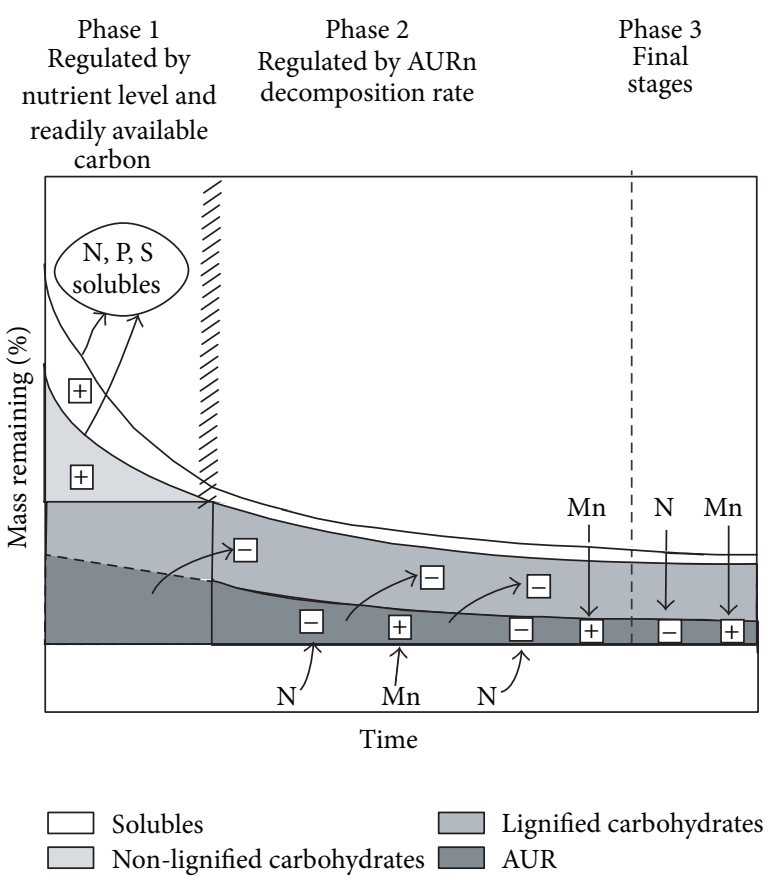

FIGURE 11: Conceptual model for rate-regulating factors and chemical changes during decomposition, modified from [28, 34]. The decomposition of water-soluble substances and unshielded cellulose/hemicellulose is stimulated by high levels of the major nutrients such as N, P, and S (early stage-phase 1). When the main part of all unshielded holocellulose is decomposed, lignin-encrusted holocellulose and lignin remain. The early phase has been suggested to last for even up to c. $40 \%$ accumulated mass loss for some pine litters [34]. For other foliar litters, for example, spruce and oak, the early phase has been found to be very short or possibly nonexisting. In the late stage-phase 2 , the degradation of lignin dominates the litter decomposition rate. Nitrogen hampers the degradation of lignin and higher $\mathrm{N}$ concentrations suppress the decomposition, whereas $\mathrm{Mn}$ appears to have a stimulating effect on the degradation of lignin and thus on litter. Finally, in the humusnear stage (phase 3), the litter decomposition rate is (close to) zero and the accumulated mass loss reaches its limit value. The model is modified according to a suggestion of Klotzbücher et al. [81]. They found that there is a loss of lignin from the start of the incubation. Still it appears that for, for example, Scots pine and other pine litters the early phase is not dominated by lignin degradation.

the early stage. We may speculate that the lignin in the foliar litter tissue is not evenly distributed. As the lignification of the living tissue goes more slowly than the growth of the cellulose and hemicellulose, part of the carbohydrates is not lignified or only to a low extent when the litter is shed. It would be reasonable to assume that Klotzbücher et al. found that lignin in less lignified tissue was degraded [61].

Although this lignin mainly appears not to have any dominant role for the decomposition or for the phases, we may accept new results [42] suggesting that there was a negative correlation between the frequency of bonds related to, for example, lignin and tannins (Aromatic-C and PhenolicC) and respiration rate from newly incubated whole litter.
This study, based on ${ }^{13} \mathrm{C}-\mathrm{NMR}$, needs further confirmation but appears to be a good example that all rate-suppressing effects in the early phase simply cannot be measured using gravimetric determinations (e.g., using litterbags). Further, it indicates an effect encompassing all bonds including both those in solubles and in solid components.

In the early phase, the mass-loss rate still may be positively related to total concentrations of the major nutrients, such as $\mathrm{N}, \mathrm{P}$, and $\mathrm{S}$, which often are limiting for decomposition rates over several species [14], among them Scots pine [40]. We may note a recent discovery by Kaspari et al. [79] that even the highly soluble sodium $(\mathrm{Na})$ has been found to be limiting for litter decomposition in areas at inland sites, namely, at a distance from sea-spray. Such an effect may apply to at least the early stage in addition to that of the main nutrients.

The stimulating effects of $\mathrm{N}$ in the early stage and its suppression of decomposition in the late one has been confirmed experimentally in three recent studies increasing the number of litter species for which the model is applicable. Using green leaves and leaf litter of white pine and pin oak with different initial concentrations of N, Hobbie et al. added inorganic $\mathrm{N}$ and organic $\mathrm{N}$ as well as a mix of the nutrients $\mathrm{P}, \mathrm{K}$, calcium $(\mathrm{Ca})$, magnesium $(\mathrm{Mg})$, and iron $(\mathrm{Fe})$ to incubated litter [77]. They also incubated litter in a stand with long-term $\mathrm{N}$ additions. Calculating $k_{\text {init }}\left(k_{A}\right)$ using an asymptotic function adapted for remaining amount, they obtained a significantly higher rate after $\mathrm{N}$ addition. We may see that decomposition of litter that had received $\mathrm{N}$ additions was stimulated and significantly faster. Effects of addition of inorganic $\mathrm{N}$ were not quite significant.

Perakis et al. [80], using Douglas fir (Pseudotsuga menziesii) needle litter with different concentrations of $\mathrm{N}$ confirmed also for this species that $\mathrm{N}$ is a limiting nutrient in the early stage. By adding $\mathrm{N}$ fertilizer (ammonium nitrate and urea), they found that the mass loss in the first 8 months increased as compared to the unfertilized litter. They obtained a significant relationship between mass loss and initial litter Mn concentration in $\mathrm{N}$-fertilized plots but not in unfertilized. The initial $\mathrm{P}$ concentrations were similar among their eight litter preparations and appear not to have been limiting.

In their study, Carreiro et al. [78] used flowering dogwood, red maple, and red oak and confirmed the stimulating effect of added $\mathrm{N}$ in the early stage and a repressing effect in the late one.

Appearance Pattern of Enzyme Activities. Hobbie et al. [77] determined both cellulolytic and lignolytic enzyme activities after 6 months and 1,2, and 3 years. We may see (Figures 12 and 13) that after six months' incubation, cellulolytic activity was well measurable and that positive effects of added $\mathrm{N}$ were observed indicating a higher production of these enzymes by the decomposing microorganisms. The activity of $\beta$-glucosidase and cellobiohydrolase increased and reached a maximum after one year of incubation after which a clear decrease took place. As regards phenol oxidase and peroxidase, the activity was just measurable at the first sampling (after 6 months) but increased with incubation time (Figure 13). 

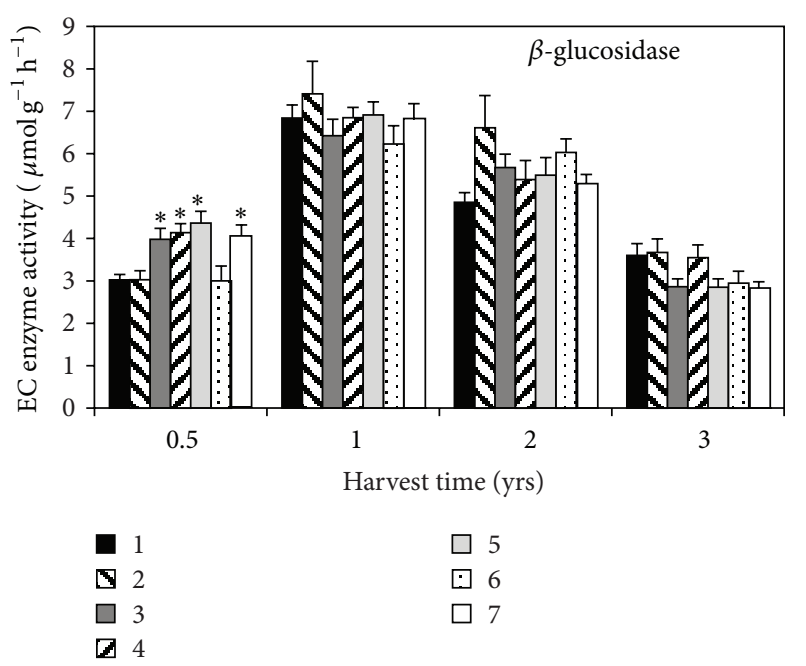

(a)
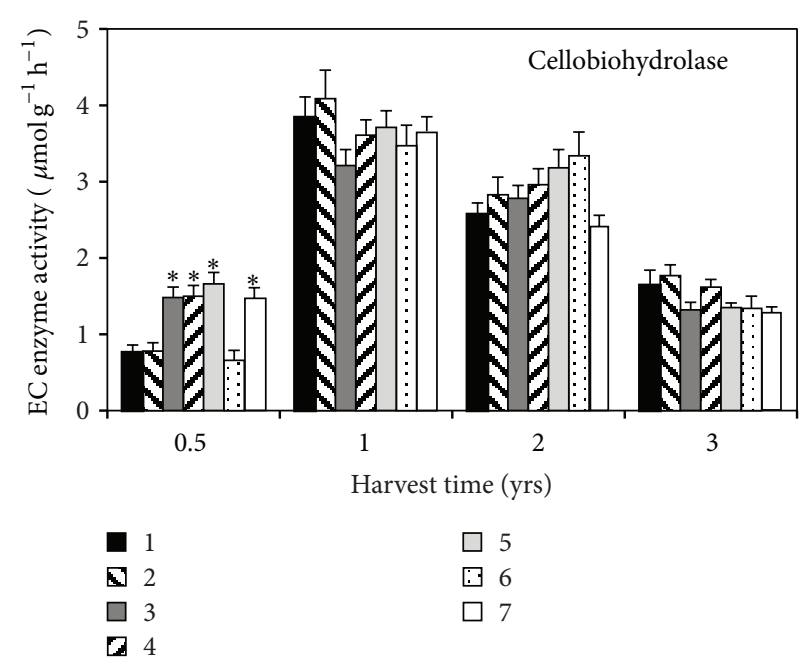

(b)

FIGURE 12: Hydrolytic enzyme activity ( $\beta$-glucosidase and cellobiohydrolase) in white pine and pin oak foliar litter harvested during the first three years of a decomposition experiment. Values are given by treatment as averaged over sites and substrates. An asterisk indicates that a particular treatment differed significantly from the control treatment at a particular harvest time. Values are means with standard error bars. Overall model $R^{2}$ values from 3-way analysis of variance (ANOVA) including treatment, site, and substrate as main effects were done separately for each harvest date and ranged from 0.25 to 0.58 for $\beta$-glucosidase, 0.24 to 0.69 for cellobiohydrolase. (1) Control, (2) carbon addition (25.5 $\mathrm{g} \mathrm{C} \mathrm{m}^{-2} \mathrm{y}^{-1}$ as glucose), (3) addition of inorganic $\mathrm{N}\left(10 \mathrm{~g} \mathrm{~N} \mathrm{~m}^{-2} \mathrm{y}^{-1}\right.$ as $\left.\mathrm{NH}_{4} \mathrm{NO}_{3}\right)$, (4) addition of carbon $\left(25.5 \mathrm{~g} \mathrm{C} \mathrm{m}^{-2} \mathrm{y}^{-1}\right.$ as glucose) and inorganic $\mathrm{N}\left(10 \mathrm{~N} \mathrm{~m}^{-2} \mathrm{y}^{-1}\right.$ as $\left.\mathrm{NH}_{4} \mathrm{NO}_{3}\right)$, (5) long-term $\mathrm{N}$ additions $\left(10 \mathrm{~g} \mathrm{~N} \mathrm{~m}^{-2} \mathrm{y}^{-1}\right.$ as $\mathrm{NH}_{4} \mathrm{NO}_{3}$ since 1999), (6) addition of non- $\mathrm{N}$ nutrients (P, K, Ca, Mg, S, Fe), (7) addition of organic $\mathrm{N}\left(10 \mathrm{~g} \mathrm{~N} \mathrm{~m}^{-2} \mathrm{y}^{-1}\right.$ as amino acids). From [77].
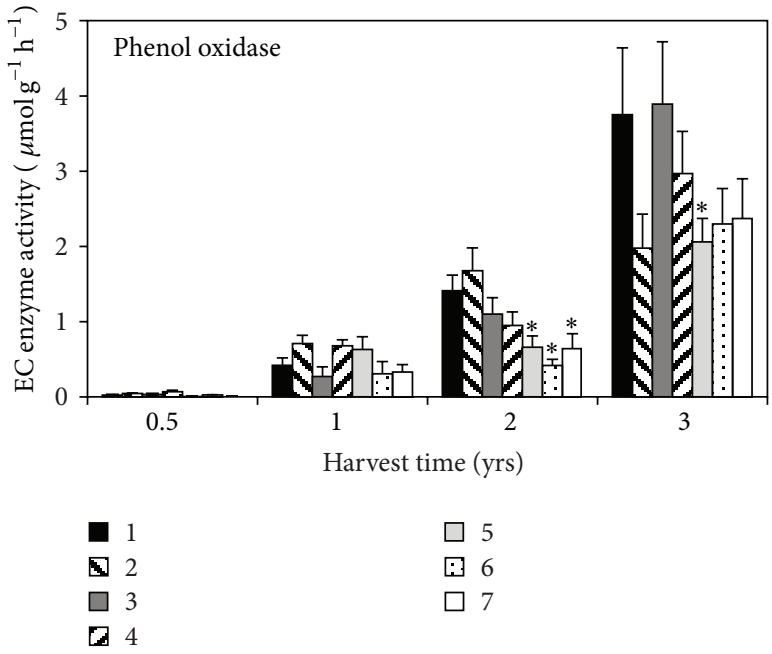

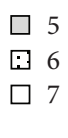

(a)

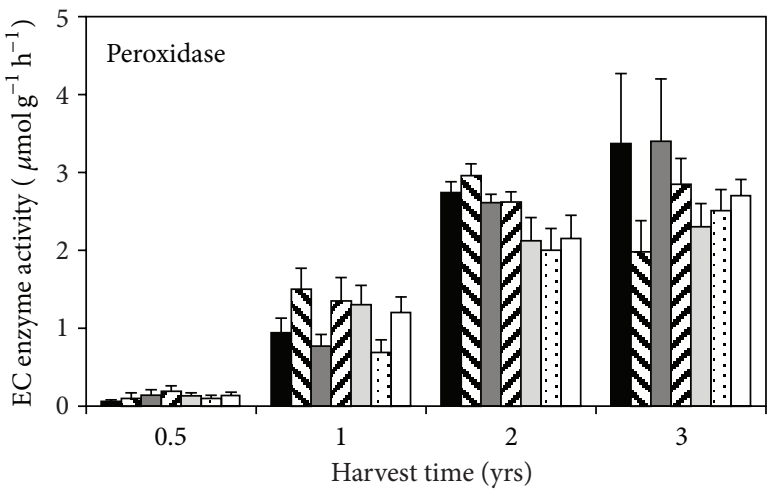

$\mathbf{1} 1$
$\mathbf{Q} 2$
$\square 3$
$\square \quad 4$

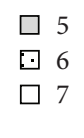

(b)

FIGURE 13: Oxidative enzyme activities (phenoloxidase and peroxidase) in white pine and pin oak foliar litter harvested during the first three years of a decomposition experiment. Values are given by treatment and averaged over sites and substrates. Statistical comparisons were only done for the 2- and 3-year harvests because of high numbers of zero values in prior harvests. An asterisk indicates that a particular treatment differed significantly from the control treatment at a particular harvest time. Values are means with standard error bars. Overall model $R^{2}$ values from 3-way analysis of variance (ANOVA) including treatment, site, and substrate as main effects were 0.34 and 0.24 for phenoloxidase and 0.22 and 0.23 after 2 and 3 years of decomposition, respectively. (1) Control, (2) carbon addition ( $25.5 \mathrm{~g} \mathrm{C} \mathrm{m}^{-2} \mathrm{y}^{-1}$ as glucose), (3) addition of inorganic $\mathrm{N}\left(10 \mathrm{~g} \mathrm{~N} \mathrm{~m}^{-2} \mathrm{y}^{-1}\right.$ as $\left.\mathrm{NH}_{4} \mathrm{NO}_{3}\right)$, (4) addition of carbon $\left(25.5 \mathrm{~g} \mathrm{C} \mathrm{m}^{-2} \mathrm{y}^{-1}\right.$ as glucose) and inorganic $\mathrm{N}\left(10 \mathrm{~N} \mathrm{~m}^{-2} \mathrm{y}^{-1}\right.$ as NH $\left.\mathrm{NO}_{3}\right)$, (5) long-term $\mathrm{N}$ additions (10 $\mathrm{g} \mathrm{N} \mathrm{m}^{-2} \mathrm{y}^{-1}$ as $\mathrm{NH}_{4} \mathrm{NO}_{3}$ since 1999), (6) addition of non-N nutrients ( $\left.\mathrm{P}, \mathrm{K}, \mathrm{Ca}, \mathrm{Mg}, \mathrm{S}, \mathrm{Fe}\right),(7)$ addition of organic $\mathrm{N}\left(10 \mathrm{~g} \mathrm{~N} \mathrm{~m}^{-2} \mathrm{y}^{-1}\right.$ as amino acids). From [77]. 
Climate Influence. For newly shed litter, it appears that climate may influence litter mass-loss rate. For local needle litter of Scots pine, it has been possible to demonstrate a clear influence of climate on decomposition rate, using the range in climate within a $2000 \mathrm{~km}$-long gradient [7]. The mass loss in the first year ranged from about $10.9 \%$ in northern Finland (close to Barents Sea) to about $43.7 \%$ in northern Germany. The dominant rate-regulating factor was the climate, as indexed by annual actual evapotranspiration (AET) or by mean annual temperature (MAT), and none of the substratequality factors alone was significant. Using unified Scots pine litter, Berg et al. [3] showed the climate relationship in a gradient from northern Finland to southern United States (southern Georgia). Such effects of climate could thus be recorded for local and unified pine needle litter in pine forests with their relatively open canopy covers.

Still, a more general relationship was demonstrated [4]. By combining available data for broadleaf and coniferous litter, the authors found a relationship between first-year mass loss and MAT. The geographic range was considerable and extended from the Equator to north Scandinavia. However, when investigating separate functional groups, the authors found clear differences among pine species, spruce, and oak species. Thus, mass-loss rate for pine litter was in highly significant and positive linear relationship to MAT, whereas that of spruce showed no relationship.

The Extent of the Early Phase and a Possible Transition Stage between the Early and the Late Stages. The extent of the early stage has been suggested to be c. $25-27 \%$ accumulated mass loss [40,82] and later Berg and McClaugherty [34] suggested that it may extend to c. $40 \%$ accumulated mass loss. These results were based on the response of the decomposition to nutrient concentration versus that to AUR concentration. We cannot exclude, however, that both the extent of a welldefined early phase and a less clear transition phase to the late stage are more unclear and possibly there is, in addition, a temporal variation over a wide range even within one species. First, the lignification in the green leaf, even within one species may be variable among years and place of growth, which may be reflected in the litter. We do not know the size of this variation. Further, we cannot exclude that the transition between the early and the late stage will be less distinguishable with a less clear response to both climate and to concentrations of N, P, and S. Also, a negative response to $\mathrm{N}$ and a positive one to Mn may be less distinguishable (B. Berg and J. Kjønaas, unpubl.). Such a transition stage is reasonable to expect and we can expect that new analytical techniques may improve the possibility to distinguish it.

\subsubsection{The Late Stage. What Factors May Regulate Decompo-} sition Rate? Berg and Staaf [40] defined a late stage as the one in which the decomposition of gravimetric lignin/AUR dominated the mass loss of litter. This definition was later improved by Berg and Matzner [28]. In both studies, AUR was used instead of lignin. Although AUR is not really an acceptable replacement to native lignin, we may use it as an index of increasing recalcitrance. In their model, Berg and

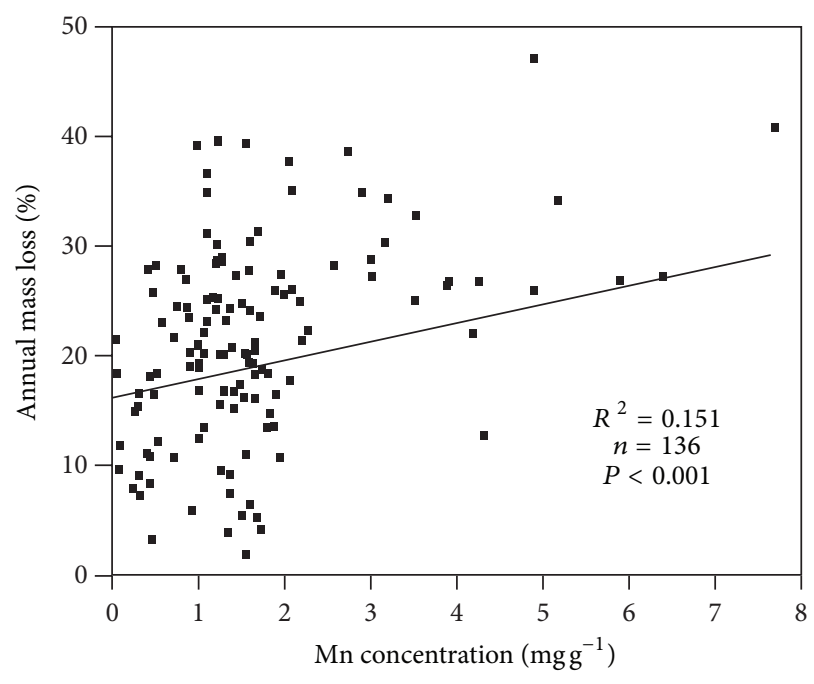

FIGURE 14: All available data (Norway spruce, lodgepole pine, Scots pine, Aleppo pine, silver birch, grey alder) for annual mass loss of foliar litter in late stages were related to litter Mn concentration at the start of each year. Mass-loss data originate from sites distributed over Sweden plus from two sites in northern Libya. From [85].

Matzner [28] included the effect of $\mathrm{N}$ concentration as a rateretarding agent of lignin decomposition (above). The positive effect of Mn on production of lignolytic enzymes [83, 84] was followed by a report on positive relationships between $\mathrm{Mn}$ concentration and litter mass-loss rate [85] (Figure 14). Such effects were found for litter of lodgepole pine and Norway spruce as well as for a mix of litter species [85].

Incubating leaves and leaf litter of white pine and pin oak in N-fertilized plots, Hobbie et al. followed the incubated litter over time. After 1 year, they found clearly reduced rates for the litter that had received $\mathrm{N}$ additions [77]. In their study on the development of cellulolytic and lignolytic enzymes in the sampled litter, they noted (i) a heavy increase in lignolytic enzymes after one year of incubation and (ii) a decrease of lignolytic enzymes after $\mathrm{N}$ additions. That study [77] supports the proposed phases.

In a study using needle litter of Douglas fir [80], a significant decrease (late stage) was found in mass-loss rates after additions of ammonium nitrate.

3.3.4. The Very Late Stages and the Concept "Limit Value." First in the study of Howard and Howard [12] and later in two independent ones $[13,14]$, the concept limit value was described (Figure 15). Further, it was found that the limit values were different among litter species. A "limit value" is estimated using a function that gives an asymptotic value for the accumulated mass loss. The following one has been suggested $[13,14]$ :

$$
L_{t}=m\left(1-e^{-k t / m}\right),
$$

where $L_{t}$ is the accumulated mass loss (in percent), $t$ time in days, $k$ the decomposition rate at the beginning of decay, and $m$ the asymptotic level that the accumulated mass loss will ultimately reach, normally not $100 \%$ and often considerably 


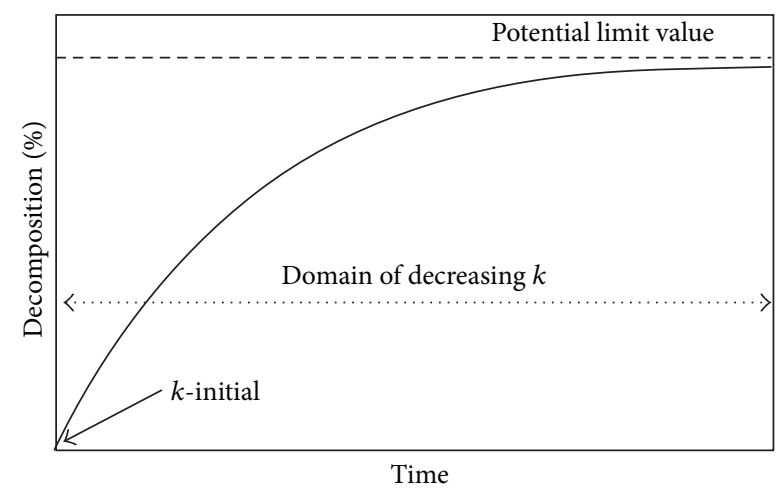

Figure 15: Decomposition rates for decomposing litter gradually decrease and the accumulated mass loss may approach an asymptote, a limit value. The process may be described using (3), which may be used to estimate the decomposition rate at any point in time. The initial decomposition rate $(k$-initial) gives the rate at time 0 from [34].

less. From a high initial value at time zero its value decreases as the process proceeds and the rate may reach the value zero at the limit value (Figure 15). The $k$ of this function should not be directly compared to rate constants estimated with other models.

Available literature data [19] allowed the estimation of all 106 limit values for foliar litter decomposing in natural systems. When regressing these against the initial $\mathrm{N}$ concentrations, a highly significant and negative relationship was obtained $\left(R^{2}=0.323 ; n=106 ; P<0.001\right)$. Later, [76] a highly significant relationship was found between 149 limit values and initial $\mathrm{N}$ concentration. The possible causal background to this relationship between limit values and $\mathrm{N}$ has been discussed (above). The fact that in this large data set the relationship to $\mathrm{N}$ concentration was significant may indicate a general effect of $\mathrm{N}$ over a good number of species, in that case 16 ones. Thus it may encompass both deciduous and coniferous litter and ecosystems in boreal and temperate forests.

However, in a study on limit values for just one litter genus, namely, pine (Pinus spp.) needle litter, mainly that of Scots pine, Berg et al. [41], using backward elimination and local litter in a climatic gradient, found that initial Mn concentration was the only significant factor for limit values. The backward elimination procedure simply removed the non-significant factors stepwise and out of ten ones, namely, MAT, MAP, water solubles, AUR, and six main nutrients only $\mathrm{Mn}$ was selected as a significant factor. Using the same data set, Berg and McClaugherty [34] applied a quadratic function of the type $-X^{2}+X$ and obtained a highly significant and improved relationship. That relationship was based on litter from four pine species and a range in litter Mn concentrations from $0.03 \mathrm{mg} \mathrm{g}^{-1}$ to $3.1 \mathrm{mg} \mathrm{g}^{-1}$. That data set originated from a climate gradient with MAT ranging from -0.7 to $17^{\circ} \mathrm{C}$. In contrast to the above finding for 16 deciduous and coniferous species [76], there was no significance for $\mathrm{N}$ in that data set using exclusively pine litter. Of the eight substrate-quality factors and two environmental ones, Mn concentration was left as the single factor.

The limit value as such is still mainly an empirical finding although we have both causal relationships and highly significant relationships to Mn concentrations. Further, using a single genus (Pinus) supported the relationship to $\mathrm{Mn}$.

In order to determine specific factors that influence the limit values it appears reasonable to study separate genera or possibly litter species. Thus, for common oak leaf litter, there was no relationship to litter Mn concentration but to that of Ca [6]. An attempt to relate limit values for Norway spruce to litter Mn concentration was not successful. However, Berg [86] found a significant and positive relationship for limit values and Ca concentration for Norway spruce litter. Thus, with two studies giving similar results, we cannot exclude that an effect of $\mathrm{Ca}$ on limit values may be related to at least these litter species.

Still, using available data, we may see some general trends. Berg et al. [76] using a data set with 149 limit values to initial litter concentrations of both $\mathrm{N}$ and Mn obtained highly significant relationships in both cases (Figure 17).

We have mentioned (above) that the litter becomes increasingly enriched in the AUR complex, including recombination products, the stability of which appears to be related to both $\mathrm{N}$ and $\mathrm{Mn}$. However, of substrate-quality factors, we cannot neglect the possible role of the increasing concentrations of heavy metals such as $\mathrm{Cu}, \mathrm{Pb}, \mathrm{Fe}$, and $\mathrm{Zn}$. There are few data revealing the dynamics of these four heavy metals, but some data has been published for decomposing Scots pine needle litter [32, 34]. For Scots pine litter, all four heavy metals increased in concentration when related to accumulated mass loss. Such concentration increases may be correlated to that of $\mathrm{N}$ and could explain part of the significant relationships.

Pine litter appears in general to have linear net release of Mn [76]. With Mn release being linear to accumulated mass loss, it may well be correlated to the increasing concentrations of $\mathrm{N}$ and to the increasing concentrations of the above heavy metals. For all cases (Mn, N, and heavy metals), we may see potential causal relationships to a retarded decomposition. Still, the roles of the main heavy metals need to be clarified, although we may keep in mind that such a role may be related to site properties, too.

\subsection{Decomposition Patterns}

Patterns, Functions and Influences. The decomposition patterns or the shape of accumulated mass loss plotted versus time may develop following different functions. One has been discussed, namely (3), a further one is (4) [88, 89], which describes total decomposition as follows;

$$
\ln \left(\frac{M_{t}}{M_{0}}\right)=-k t,
$$

in which $M_{0}$ is initial mass and $M_{t}$ mass at time $t, k$ is the rate constant and $t$ is time. 


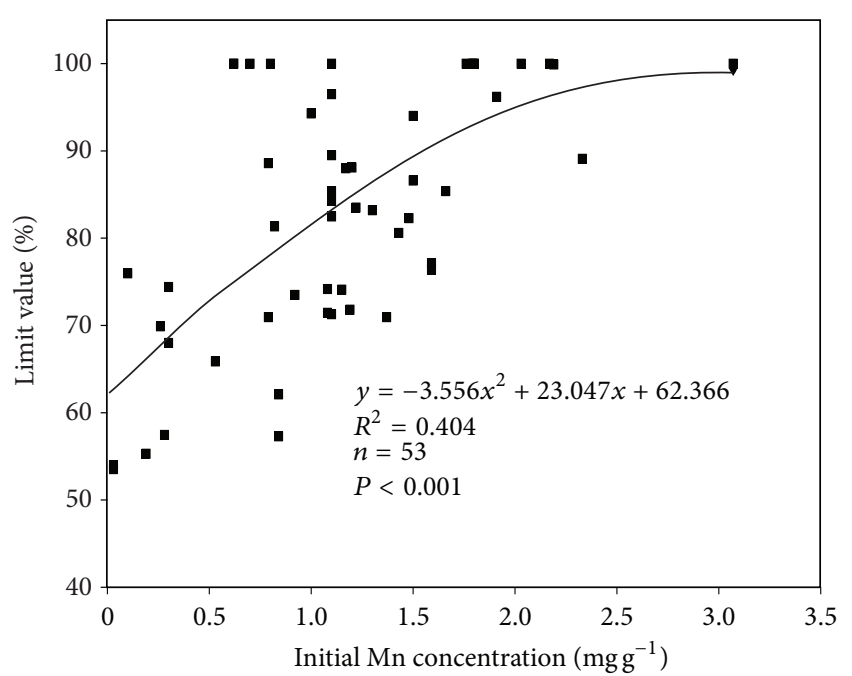

FIGURE 16: The level of the limit value, given as accumulated mass loss. The limit value for needle litter of pine (Pinus) species appears to be related to litter $\mathrm{Mn}$ concentration. Decomposition studies from four pine litter species, mainly Scots pine, were combined into a climatic gradient and limit values estimated using litter accumulated mass loss. A backward elimination procedure removed factors that were not significant. Of MAT and MAP and eight substrate-quality factors, namely, water solubles, AUR, $\mathrm{N}, \mathrm{P}, \mathrm{K}, \mathrm{Ca}, \mathrm{Mg}$, and $\mathrm{Mn}$, manganese was selected as the single significant factor. Figure from [34] based on data from [21].

Equation (3) (above) allows the calculation of a stable fraction, identified by the mass-loss rate of zero, thus separating the readily decomposed organic matter from the stabilized fraction, which may be of different sizes. This means that a graph describing the accumulated mass loss may approach very different limit values (Figure 15). Thus, the litters with different limit values (Figure 16) may be considered to have different patterns.

To discuss decomposition pattern, we may use an index and I have used the limit value as provisional index. The decomposition pattern thus differs depending on the level of the limit value. A complete decomposition with a limit value of $100 \%$ and one with a lower at, say, $45 \%$ would give different patterns or differing curvatures of the graph.

Pattern versus Litter Nutrients. It appears that the decomposition patterns for pine litter may be related to initial Mn concentrations. Manganese appears to be the dominant factor determining limit values, at least in pine ecosystems (Figure 16). In a study [21] on local, transplanted, and experimental pine needle litter, in all 56 decomposition studies ("sequences"), the role of $\mathrm{Mn}$ versus limit value was determined. Using backward elimination, Berg et al. investigated the eight substrate-quality variables $\mathrm{N}, \mathrm{P}, \mathrm{K}, \mathrm{Ca}$, $\mathrm{Mg}, \mathrm{Mn}, \mathrm{AUR}$, and water solubles plus MAT and MAP. The litter was mainly that of Scots pine but the set included lodgepole pine, stone pine, and Aleppo pine.

The positive relationship between initial concentrations of $\mathrm{Mn}$ and limit values for pine needles (Figure 16) is empirical, as is the more general relationship between $\mathrm{N}$ and limit values found in earlier studies [19] although both are based on causal relationships. In addition, the effect of $\mathrm{Mn}$ on the degradation of lignin and thus on lignified tissue as well as on the degradation of secondary products such as humic acid $[84,90]$ has been demonstrated with highly decomposed litter (Figure 14) [85].

We may speculate that the positive relationship between the limit value and the total concentration of $\mathrm{Mn}$ in highly decomposed litter arises because higher Mn concentrations enable the decomposition to proceed further before a recalcitrant fraction is developed. The formation of a very slowly decomposing fraction may occur when litter approaches its limit value because the remaining $\mathrm{Mn}$ at this stage is bound in a form that is relatively unavailable to the degrading microorganisms. The dynamics of total Mn in decomposing foliar litter are variable over litter types but have been little studied $[69,76]$.

In earlier investigations $[19,20], \mathrm{N}$ was significantly $(P<$ 0.001 ) and negatively related to limit values and the causal relationships are well established $[72,84]$. These relationships were based on available data, including 16 species (Figure 17). Although Mn was selected for pine litter [21], Berg et al. found that $\mathrm{N}$ was the last variable to be eliminated. The reason for $\mathrm{N}$ not being included in the final model for pine litter could be that $\mathrm{N}$ has no essential relationship with the limit value, and alternatively that the concentration range in $\mathrm{N}$ was too limited in the studied material.

Thus, we cannot exclude that $\mathrm{N}$ simply may have a lower influence on limit values than $\mathrm{Mn}$ in decomposition of pine needle litter, possibly because the range of initial litter $\mathrm{N}$ concentrations was relatively narrow among substrates. By contrast, the negative relationship between $\mathrm{N}$ and limit values observed by Berg [19] using 106 limit values was based on 21 different litter species/types with a wide range in initial $\mathrm{N}$ concentrations ( 2.9 to $30.7 \mathrm{mg} \mathrm{g}^{-1}$ ). However, in both cases, there are strong general causal relationships between $\mathrm{Mn}$ or $\mathrm{N}$ and the microbial degradation of lignin (and lignified tissue) that could explain these empirical relationships [84, 91].

Can climate influence the pattern? The parameter MAT may deserve to be commented upon. There is a relationship between litter Mn concentration in foliar litter and MAT as well as one between MAT/AET and N concentration. Already in 1995, a highly significant and negative relationship was found between Mn concentration in the newly shed pine needle litter and MAT, suggesting that litter Mn concentration may also reflect the local climate [48]. The corresponding relationship to $\mathrm{N}$ concentration was positive.

These results suggest that higher MAT is associated with lower $\mathrm{Mn}$ and higher $\mathrm{N}$ concentrations in the needle litter that is formed at a given site. Although the mechanism underlying these relationships needs further studies, an effect of MAT on $\mathrm{Mn}$ and $\mathrm{N}$ concentrations in litter may influence the fraction of organic matter that becomes recalcitrant, leading to a regional and climate-related variation in the formation of recalcitrant organic matter from Pinus.

We discussed the strong variation in the quotient N-to$\mathrm{Mn}$ in newly shed litter over a climatic gradient and gave the ratio of 2.5 at a $\mathrm{MAT}$ of $0^{\circ} \mathrm{C}$, at $10^{\circ} \mathrm{C}$ it was 10 times as high and at $17^{\circ}$ more than 50 times higher. Using the 


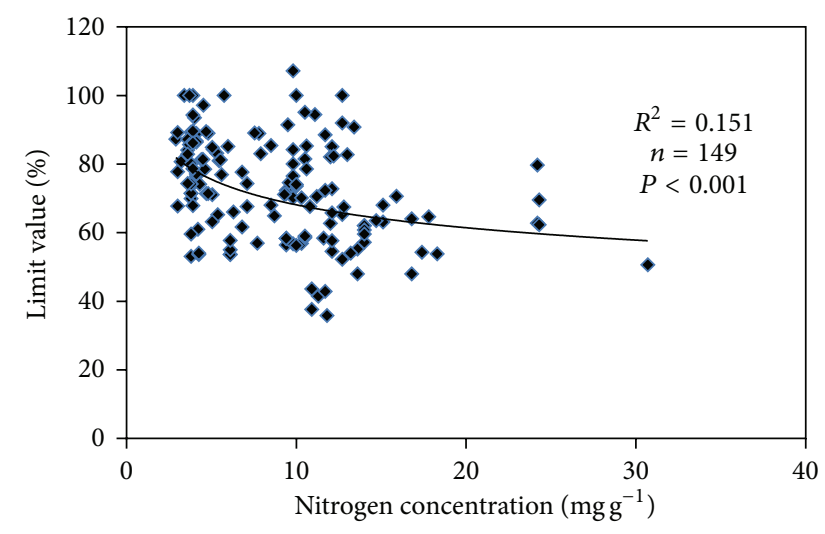

(a)

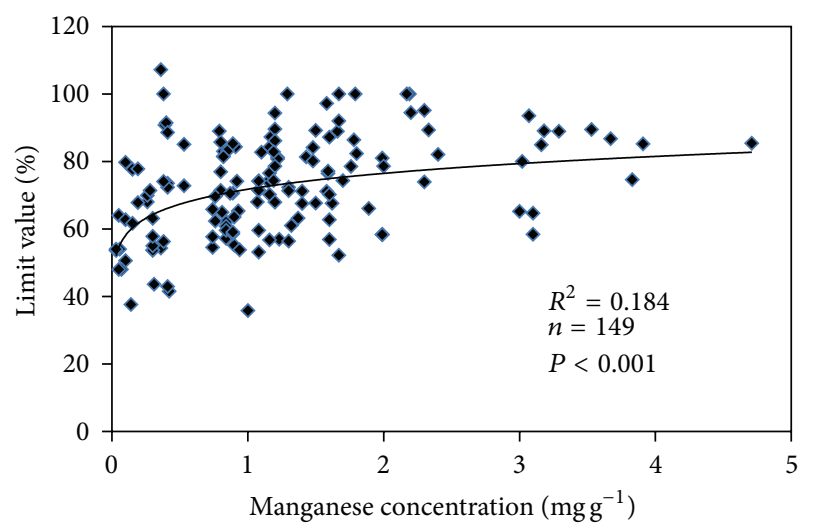

(b)

FIGURE 17: Relationships (power function) between initial litter concentration of $\mathrm{N}$ and $\mathrm{Mn}$ and limit values. (a) Nitrogen, (b) Manganese. In both cases, the same set of data was used with 149 decomposition studies and 16 species included (DELILA II database, http://www.eko.uj.edu.pl/deco/). Figure from [87].

available information of the roles of $\mathrm{N}$ and $\mathrm{Mn}$, the litter chemical composition thus would influence the pattern and give a less degradable litter at a warmer climate-unless so far unknown factors influence the litter's degradability. So far the decomposition studies appear to have confirmed this for pine litter.

\subsection{Carbon Sequestration: Amounts and Patterns}

3.5.1. Can We Use Limit Values to Estimate C Sequestration Rates in Humus Layers? We defined the limit value based on accumulated litter mass loss (3). Although we have defined the limit value by estimating the accumulated mass loss at which the rate becomes 0 for a given fraction, it does not mean that the "stable" fraction is completely stable or biologically undegradable. We may only conclude that the biological degradation is slow [82]. Although we appear to have very little direct information, we may speculate about how slow it may be and if this rate may change. Coûteaux et al. [82] comparing decomposition rates of Scots pine humus and far-decomposed litter (close to the limit value) obtained a rate of "less than $0.0001 \% \mathrm{~d}^{-1}$ " or less than $0.037 \%$ per year.
For our discussion, we may call the remaining stable fraction "humus" and ask about what factors that influence its stability. Berg and Matzner [28], quoting Bringmark and Bringmark [29], reported that a high $\mathrm{N}$ concentration was rate-suppressing for respiration from humus-layer samples collected over a region. Still, total $\mathrm{N}$ concentration was just one factor and we have no answer to how many further factors there are.

If a sample of a humus layer is taken out from its environment, we may measure its respiration rate and several studies give rates that sometimes correspond to $100 \%$ decomposition in a short time, even less than a year. Still, with the humus undisturbed, the humus layer will last and grow, and undisturbed humus layers have been found to develop for close to 3000 years reaching a depth of almost 1.5 meters [23].

Although foliar litter is not the only litter component, forming humus layers, it is a major one and in some ecosystems even the dominant one. Using data from a Scots pine monoculture c. 120 years old, with a humus layer developed on ashes from the latest forest fire, it has been possible to reconstruct the amount of stored carbon in the humus layer $[24,26]$ using extensive litter-fall data and an average limit value of $89.0 \%(n=8)$. A similar calculation was made for the close to 3000 year-old humus layers described by Wardle et al. [23] and a quantitative reconstruction was made of three groups of humus layers with the average age of 1106, 2081, and 2984 years $[24,26]$.

3.5.2. Tree Species Influence the C Sequestration Rate. Several attempts have been made to study the accumulation rate of humus in humus layers, the "primary sequestration" [46]. In most cases, this appears to have been made in monocultures or tree species trials. The experiment of Ovington [92] showed clearly that there was a linear relationship between stand age and the increase in mass (and C) in the LFH layer on top of mineral soil.

The rate of $\mathrm{C}$ sequestration in a well-developed humus layer is easily determined using gravimetric measurements of the humus-layer $\mathrm{C}$ and a comparison to the time for its buildup. Still, there are relatively few such values reported in the scientific literature, possibly due to the long accumulation time and the absolute request for good information about stand history and the humus layer when the buildup started.

To evaluate the effect of tree species on $\mathrm{C}$ sequestration rates, Berg and McClaugherty [34] made an evaluation of existing data and focused on two larger studies, one in Denmark [37] and one in the UK [38], together encompassing 10 trials with c. 16 tree species in paired stands. Each of these studies was made with the purpose of evaluating several tree species, which also were occurring in both studies. With a similarity in climate, this allowed an evaluation of the species ability to sequester $\mathrm{C}$ in the humus layer. Site history was given [38, 93].

An analysis of variance gave a rather clear response in spite of a high variation in sequestered carbon. Berg and McClaugherty [34] distinguished that coniferous species/ genera had a significantly higher sequestration rate-twice as high-as deciduous species (Figure 18). They found three main groups with pine and spruce species having the highest 
Pine Spruce

\begin{tabular}{|c|c|c|c|c|c|c|}
\hline & & Fir & Larch & Beech & & \\
\hline & & & & - Grand fir & Other decid & Oak spp \\
\hline 481 & 355 & 266 & 283 & 196 & 112 & 103 \\
\hline
\end{tabular}

FIGURE 18: Data from 7 tree species trials in Denmark [37] and 3 in England [38]. Each of the studies reported a carefully determined amount of soil organic matter on top of the mineral soil in monocultural stands, "primary sequestration" [46]. Data were combined to analyse and determine the variation among genera [34]. The full line underlining genus names gives $\mathrm{C}$ accumulation rates that are not significantly different. Ash was subtracted and $50 \% \mathrm{C}$ was assumed for the organic matter of Ovington's study [38]. Compiled data and figure are from [34].

sequestration rate, followed by fir, larch, and beech and in the third place "other deciduous." A similar observation was the evaluation of Berg [94], based on existing data [95, 96] comparing sequestration rates over 30 years in paired stands and observing about twice as high a rate in a Norway spruce stand as compared to one with common beech (Fagus sylvatica).

\subsubsection{Regional Approach to Determine C Sequestration Rates} in Well-Developed Humus Layers. We may argue that sequestration rates should be related to both foliar litter fall, and the size of the stable residue. However, in a comparison of litter fall from Scots pine and Norway spruce over Sweden [50, 97], a higher foliar litter fall was found for Norway spruce than for Scots pine. Still, the $\mathrm{C}$ sequestration rate in humus layers was higher in Scots pine stands when rates were compared for Sweden as a region [98].

In two attempts to calculate the $\mathrm{C}$ sequestration in the humus layer over a region using countrywide (Sweden), directly measured data, Berg et al. obtained sequestration rates [98] that were close to those estimated for the same region using limit values [97]. In a comparison [99], three different approaches were compared for the same region (the forested land of Sweden), providing similar results.

Although the numbers obtained by a calculation using limit values can be verified by direct measurements, we cannot exclude the possibility that calculations using litter fall data and limit values rather give an index for $\mathrm{C}$ sequestration. We may consider that there are several litter components that may be degraded with different decomposition patterns, which additionally may differ among species and ecosystems.

\section{Conflict of Interests}

The author declares that there is no conflict of interests regarding the publication of this paper.

\section{References}

[1] C. E. Prescott, "Do rates of litter decomposition tell us anything we really need to know?" Forest Ecology and Management, vol. 220, pp. 66-74, 2005.
[2] V. Meentemeyer, "Macroclimate and lignin control of litter decomposition rates," Ecology, vol. 59, pp. 465-472, 1978.

[3] B. Berg, M. P. Berg, P. Bottner et al., "Litter mass loss rates in pine forests of Europe and Eastern United States: some relationships with climate and litter quality," Biogeochemistry, vol. 20, no. 3, pp. 127-153, 1993.

[4] H. Kang, B. Berg, C. Liu, and C. J. Westman, "Variation in massloss rate of foliar litter in relation to climate and litter quality in eurasian forests: differences among functional groups of litter," Silva Fennica, vol. 43, no. 4, pp. 549-575, 2009.

[5] B. Berg, M.-B. Johansson, and V. Meentemeyer, "Litter decomposition in a transect of Norway spruce forests: substrate quality and climate control," Canadian Journal of Forest Research, vol. 30, no. 7, pp. 1136-1147, 2000.

[6] M. P. Davey, B. Berg, B. A. Emmett, and P. Rowland, "Decomposition of oak leaf litter is related to initial litter Mn concentrations," Canadian Journal of Botany, vol. 85, no. 1, pp. 16-24, 2007.

[7] M. B. Johansson, B. Berg, and V. Meentemeyer, "Litter massloss rates in late stages of decomposition in a climatic transect of pine forests. Long-term decomposition in a Scots pine forest. IX," Canadian Journal of Botany, vol. 73, no. 10, pp. 1509-1521, 1995.

[8] R. Fogel and K. Cromack, "Effect of habitat and substrate quality on Douglas fir litter decomposition in western Oregon," Canadian Journal of Botany, vol. 55, pp. 1632-1640, 1977.

[9] C. M. Preston, J. R. Nault, J. A. Trofymow, C. Smyth, and The CIDET Working Group, "Chemical changes during 6 years of decomposition of 11 litters in some Canadian forest sites. Part 1: elemental composition, tannins, phenolics, and proximate fractions," Ecosystems, vol. 12, no. 7, pp. 1053-1077, 2009.

[10] C. M. Preston, J. R. Nault, J. A. Trofymow, and The CIDET Working Group, "Chemical changes during 6 years of decomposition of 11 litters in some Canadian forest sites. Part $2:{ }^{13} \mathrm{C}$ abundance, solid-state ${ }^{13} \mathrm{C}$ NMR spectroscopy and the meaning of 'lignin,"' Ecosystems, vol. 12, no. 7, pp. 1078-1102, 2009.

[11] T. Persson, E. Bååth, M. Clarholm et al., "Trophic structure, biomass dynamics and carbon metabolism of soil organisms in a Scots pine forest," Ecological Bulletins, vol. 32, pp. 419-462, 1980.

[12] P. J. A. Howard and D. M. Howard, "Microbial decomposition of tree and shrub leaf litter. I. Weight loss and chemical composition of decomposing litter," Oikos, vol. 25, no. 3, pp. 341-352, 1974.

[13] R. K. Wieder and G. E. Lang, "A critique of the analytical methods used in examining decomposition data obtained from litter bags," Ecology, vol. 63, no. 6, pp. 1636-1642, 1982.

[14] B. Berg and G. Ekbohm, "Litter mass-loss rates and decomposition patterns in some needle and leaf litter types. Long-term decomposition in a Scots pine forest. VII," Canadian Journal of Botany, vol. 69, no. 7, pp. 1449-1456, 1991.

[15] B. Berg and G. Ekbohm, "Decomposing needle litter in Pinus contorta (lodgepole pine) and Pinus sylvestris (Scots pine) monocultural systems - is there a maximum mass loss?" Scandinavian Journal of Forest Research, vol. 8, no. 4, pp. 457-465, 1993.

[16] W. S. Currie, M. E. Harmon, I. C. Burke, S. C. Hart, W. J. Parton, and W. Silver, "Cross-biome transplants of plant litter show decomposition models extend to a broader climatic range but lose predictability at the decadal time scale," Global Change Biology, vol. 16, no. 6, pp. 1744-1761, 2010.

[17] M. E. Harmon, W. L. Silver, B. Fasth et al., "Long-term patterns of mass loss during the decomposition of leaf and fine root litter: 
an intersite comparison," Global Change Biology, vol. 15, no. 5, pp. 1320-1338, 2009.

[18] B. Berg, R. Laskowski, and A. Virzo De Santo, "Estimated nitrogen concentrations in humus based on initial nitrogen concentrations in foliar litter: a synthesis. XII. Long-term decomposition in a Scots pine forest," Canadian Journal of Botany, vol. 77, no. 12, pp. 1712-1722, 1999.

[19] B. Berg, "Litter decomposition and organic matter turnover in northern forest soils," Forest Ecology and Management, vol. 133, no. 1-2, pp. 13-22, 2000.

[20] B. Berg, G. Ekbohm, M. Johansson, C. McClaugherty, F. Rutigliano, and A. V. De Santo, "Maximum decomposition limits of forest litter types: a synthesis," Canadian Journal of Botany, vol. 74, no. 5, pp. 659-672, 1996.

[21] B. Berg, A. De Marco, M. P. Davey et al., "Limit values for foliar litter decomposition-pine forests," Biogeochemistry, vol. 100, no. 1, pp. 57-73, 2010.

[22] B. Berg, "Scots pine needle litter-can it give a mechanism for carbon sequestration?" Geografia Polonica, vol. 85, no. 2, pp. 1323, 2012.

[23] D. A. Wardle, O. Zackrisson, G. Hörnberg, and C. Gallet, "The influence of island area on ecosystem properties," Science, vol. 277, no. 5330, pp. 1296-1299, 1997.

[24] B. Berg, C. McClaugherty, A. Virzo De Santo, and D. Johnson, "Humus buildup in boreal forests: effects of litter fall and its $\mathrm{N}$ concentration," Canadian Journal of Forest Research, vol. 31, no. 6, pp. 988-998, 2001.

[25] K. E. Rehfüss, Waldböden, Entwicklung, Eigenschaften und Nutzung, vol. 29 of Pareys Studientexte, Parey, Hamburg, Germany, 2nd edition, 1990, (German).

[26] B. Berg and N. Dise, "Calculating the long-term stable nitrogen sink in northern European forests," Acta Oecologica, vol. 26, no. 1, pp. 15-21, 2004.

[27] B. Berg and N. Dise, "Validating a new model for N sequestration in forest soil organic matter," Water, Air, and Soil Pollution, vol. 4, no. 2-3, pp. 343-358, 2004.

[28] B. Berg and E. Matzner, "Effect of N deposition on decomposition of plant litter and soil organic matter in forest systems," Environmental Reviews, vol. 5, no. 1, pp. 1-25, 1997.

[29] E. Bringmark and L. Bringmark, "Large-scale pattern of mor layer degradation in Sweden measured as standardized respiration," in Humic Substances in the Aquatic and Terrestrial Environments. Proceedings of an International Symposium, Linköping, Sweden, August 1989, vol. 33 of Lecture notes in earth sciences, pp. 255-259, Springer, Berlin, Germany, 1991.

[30] G. Guggenberger, "Acidification effects on dissolved organic matter mobility in spruce forest ecosystems," Environment International, vol. 20, no. 1, pp. 31-41, 1994.

[31] B. Berg, K. Hannus, T. Popoff, and O. Theander, "Changes in organic chemical components of needle litter during decomposition. Long-term decomposition in a Scots pine forest: I," Canadian Journal of Botany, vol. 60, no. 8, pp. 1310-1319, 1982.

[32] B. Berg and C. McClaugherty, Plant Litter. Decomposition. Humus Formation. Carbon Sequestration, Springer, Berlin, Germany, 2nd edition, 2008.

[33] H. Kang, Z. Xin, B. Berg et al., "Global patterns of leaf litter nitrogen and phosphorus stoichiometry in woody plants with latitude and climatic factors," Annals of Forest Science, vol. 67, pp. 811-818, 2010.

[34] B. Berg and C. A. McClaugherty, Plant Litter. Decomposition. Humus Formation. Carbon Sequestration, Springer, Berlin, Germany, 3rd edition, 2014.
[35] B. Berg, A. Virzo De Santo, F. A. Rutigliano, A. Fierro, and G. Ekbohm, "Limit values for plant litter decomposing in two contrasting soils-influence of litter elemental composition," Acta Oecologica, vol. 24, no. 5-6, pp. 295-302, 2003.

[36] B. Wessén and B. Berg, "Long-term decomposition of barley straw: chemical changes and ingrowth of fungal mycelium," Soil Biology and Biochemistry, vol. 18, no. 1, pp. 53-59, 1986.

[37] L. Vesterdal and K. Raulund-Rasmussen, "Forest floor chemistry under seven tree species along a soil fertility gradient," Canadian Journal of Forest Research, vol. 28, no. 11, pp. 16361647, 1998.

[38] J. D. Ovington, "Studies on the development of woodland conditions under different trees. II. The forest floor," The Journal of Ecology, vol. 42, pp. 71-80, 1954.

[39] B. Berg, C. Liu, R. Laskowski et al., "Relationships between nitrogen, AUR, and climate among tree foliar litters," Canadian Journal of Forest Research, vol. 43, pp. 103-107, 2013.

[40] B. Berg and H. Staaf, "Decomposition rate and chemical changes of Scots pine needle litter. II. Influence of chemical composition," in Structure and Function of Northern Coniferous Forests. An Ecosystem Study, T. Persson, Ed., vol. 32, pp. 373-390, Ecological Bulletins, Stockholm, Sweden, 1980.

[41] B. Berg and C. O. Tamm, "Decomposition and nutrient dynamics of litter in long-term optimum nutrition experiments. II.Nutrient concentrations in decomposing Picea abies needle litter," Scandinavian Journal of Forest Research, vol. 9, no. 2, pp. 99-105, 1994.

[42] B. Erhagen, M. Öquist, T. Sparrman et al., “Temperature response of litter and soil organic matter decomposition is determined by chemical composition of organic material," Global Change Biology, 2013.

[43] A. De Marco, R. Spaccini, P. Vittozzi et al., "Decomposition of black locust and black pine leaf litter in two coeval forest stands on Mount Vesuvius and dynamics of organic components assessed through proximate analysis and NMR spectroscopy," Soil Biology and Biochemistry, vol. 51, pp. 1-15, 2012.

[44] B. Berg, H. G. W. Booltink, A. Breymeyer et al., "Data on needle litter decomposition and soil climate as well as site characteristics for some coniferous forest sites. 2nd ed. Section 2. Data on needle litter decomposition," Report 42, Departments of Ecology and Environmental Research. Swedish University of Agricultural Sciences, 1991.

[45] K. A. Thorn and M. A. Mikita, "Ammonia fixation by humic substances: a nitrogen-15 and carbon-13 NMR study," Science of the Total Environment, vol. 113, no. 1-2, pp. 67-87, 1992.

[46] B. Berg, C. McClaugherty, and A. Virzo De Santo, "Practicalities of estimating carbon sequestration," CAB Reviews, vol. 3, no. 84, pp. 1-15, 2008.

[47] G. Tyler, "Changes in the concentrations of major, minor and rare-earth elements during leaf senescence and decomposition in a Fagus sylvatica forest," Forest Ecology and Management, vol. 206, pp. 167-177, 2005.

[48] B. Berg, R. Calvo de Anta, A. Escudero et al., "The chemical composition of newly shed needle litter of Scots pine and some other pine species in a climatic transect. X. Long-term decomposition in a Scots pine forest," Canadian Journal of Botany, vol. 73, no. 9, pp. 1423-1435, 1995.

[49] C. Liu, B. Berg, W. Kutsch et al., "Leaf litter nitrogen concentration as related to climatic factors in Eurasian forests," Global Ecology and Biogeography, vol. 15, no. 5, pp. 438-444, 2006. 
[50] B. Berg and V. Meentemeyer, "Litter fall in some European coniferous forests as dependent on climate: a synthesis," Canadian Journal of Forest Research, vol. 31, no. 2, pp. 292-301, 2001.

[51] C. Liu, C. J. Westman, B. Berg et al., "Variation in litterfallclimate relationships between coniferous and broadleaf forests in Eurasia," Global Ecology and Biogeography, vol. 13, no. 2, pp. 105-114, 2004.

[52] B. Berg and J. E. Lundmark, "Decomposition of needle litter in Pinus contorta and Pinus sylvestris monocultures-a comparison," Scandinavian Journal of Forest Research, vol. 2, pp. 3-12, 1987.

[53] B. Berg and C. O. Tamm, "Decomposition and nutrient dynamics of Norway spruce needle litter in a long-term optimum nutrition experiment. I. Organic matter decomposition," Tech. Rep. 39, Department of Ecology and Environmental Sciences. Swedish University of Agricultural Sciences, 1991.

[54] C. A. McClaugherty, "Soluble polyphenols and carbohydrates in throughfall and leaf litter decomposition," Acta Oecologia, vol. 4, pp. 375-385, 1983.

[55] L. Bogatyrev, B. Berg, and H. Staaf, "Leaching of plant nutrients and total phenolic substances from some foliage litters. A laboratory study," Tech. Rep. 33, Swedish Coniferous Forest Project, 1983.

[56] K. Ono, S. Hiradate, S. Morita, K. Ohse, and K. Hirai, "Humification processes of needle litters on forest floors in Japanese cedar (Cryptomeria japonica) and Hinoki cypress (Chamaecyparis obtusa) plantations in Japan," Plant and Soil, vol. 338, no. 1, pp. 171-181, 2011.

[57] J. D. Aber, C. A. McClaugherty, and J. M. Melillo, Litter Decomposition in Wisconsin Forests-Mass Loss, Organic-Chemical Constituents and Nitrogen, vol. R3284 of University of Wisconsin Research Bulletins, University of Wisconsin, Madison, Wis, USA, 1984.

[58] M. Y. Faituri, "Soil organic matter in Mediterranean and Scandinavian forest ecosystems and dynamics of nutrients and monomeric phenolic compounds," Silvestra, vol. 236, 136 pages, 2002.

[59] B. Berg, G. Ekbohm, and C. McClaugherty, "Lignin and holocellulose relations during long-term decomposition of some forest litters. Long-term decomposition in a Scots pine forest. IV," Canadian Journal of Botany, vol. 62, no. 12, pp. 2540-2550, 1984.

[60] J. M. Melillo, J. D. Aber, A. E. Linkins et al., "Carbon and nitrogen dynamics along the decay continuum: plant litter to soil organic matter," in Ecology of Arable Lands, M. Clarholm and L. Bergström, Eds., pp. 53-62, Kluwer, Dordrecht, The Netherlands, 1989.

[61] T. Klotzbücher, T. R. Filley, K. Kaiser, and K. Kalbitz, "A study of lignin degradation in leaf and needle litter using ${ }^{13} \mathrm{C}$-labelled tetramethylammonium hydroxide (TMAH) thermochemolysis: comparison with $\mathrm{CuO}$ oxidation and van Soest methods," Organic Geochemistry, vol. 42, no. 10, pp. 1271-1278, 2011.

[62] S. Güsewell and J. T. A. Verhoeven, "Litter N : P ratios indicate whether $\mathrm{N}$ or P limits the decomposability of graminoid leaf litter," Plant and Soil, vol. 287, no. 1-2, pp. 131-143, 2006.

[63] B. Berg and H. Staaf, "Leaching, accumulation and release of nitrogen in decomposing forest litter," in Terrestrial Nitrogen Cycles. Processes, Ecosystem Strategies and Management Impacts, F. E. Clark and T. Rosswall, Eds., vol. 33, pp. 163-178, Ecological Bulletins, Stockholm, Sweden, 1981.

[64] S. Manzoni, R. B. Jackson, J. A. Trofymow, and A. Porporato, "The global stoichiometry of litter nitrogen mineralization," Science, vol. 321, no. 5889, pp. 684-686, 2008.
[65] J. D. Aber and J. M. Melillo, Terrestrial Ecosystems, Cengage Learning. Emea, 1991.

[66] B. Berg and R. Laskowski, Litter Decomposition: A Guide to Carbon and Nutrient Turnover, vol. 38 of Advances in Ecological Research, Elsevier, San Diego, Calif, USA, 2006.

[67] B. Berg, C. McClaugherty, and M. B. Johansson, "Chemical changes in decomposing plant litter can be systemized with respect to the litter's initial chemical composition," Reports from the Departments in Forest Ecology and Forest Soils, Swedish University of Agricultural Sciences. Report 74, 1997.

[68] J. D. Aber and J. M. Melillo, "Nitrogen immobilization in decaying hardwood leaf litter as a function of initial nitrogen and lignin content," Canadian Journal of Botany, vol. 60, no. 11, pp. 2263-2269, 1982.

[69] B. Berg and J. Cortina, "Nutrient dynamics in some decomposing leaf and needle litter types in a Pinus sylvestris forest," Scandinavian Journal of Forest Research, vol. 10, no. 1, pp. 1-11, 1995.

[70] H. Staaf and B. Berg, "Accumulation and release of plant nutrients in decomposing Scots pine needle litter. Long-term decomposition in a Scots pine forest: II," Canadian Journal of Botany, vol. 60, no. 8, pp. 1561-1568, 1982.

[71] B. Berg, "Dynamics of nitrogen $\left({ }^{15} \mathrm{~N}\right)$ in decomposing Scots pine (Pinus sylvestris) needle litter. Long-term decomposition in a Scots pine forest. VI," Canadian Journal of Botany, vol. 66, no. 8, pp. 1539-1546, 1988.

[72] H. Nömmik and K. Vahtras, "Retention and fixation of ammonium and ammonia in soils," in Nitrogen in Agricultural Soils, F. J. Stevenson, Ed., vol. 22 of Agronomy Monographs, pp. 123-171, Agronomy Society of America, Madison, Wis, USA, 1982.

[73] G. Axelsson and B. Berg, "Fixation of ammonia $\left({ }^{15} \mathrm{~N}\right)$ to Scots pine needle litter in different stages of decomposition," Scandinavian Journal of Forest Research, vol. 3, pp. 273-280, 1988.

[74] M. R. Lindbeck and J. I. Young, "Polarography of intermediates in the fixation of nitrogen by p-quinone-aqueous ammonia systems," Analytica Chimica Acta, vol. 32, pp. 73-80, 1965.

[75] H. Knicker, "Stabilization of N-compounds in soil and organicmatter-rich sediments-what is the difference?" Marine Chemistry, vol. 92, pp. 167-195, 2004.

[76] B. Berg, B. Erhagen, M. B. Johansson et al., "Manganese dynamics in decomposing foliar litter," Canadian Journal of Forest Research, vol. 43, pp. 1-10, 2013.

[77] S. Hobbie, W. C. Eddy, C. R. Buyarski et al., "Response of decomposing litter and its microbial community to multiple forms of nitrogen enrichment," Ecological Monographs, vol. 82, pp. 389-405, 2012.

[78] M. M. Carreiro, R. L. Sinsabaugh, D. A. Repert, and D. F. Parkhurst, "Microbial enzyme shifts explain litter decay responses to simulated nitrogen deposition," Ecology, vol. 81, no. 9, pp. 2359-2365, 2000.

[79] M. Kaspari, S. P. Yanoviak, R. Dudley, M. Yuan, and N. A. Clay, "Sodium shortage as a constraint on the carbon cycle in an inland tropical rainforest," Proceedings of the National Academy of Sciences of the United States of America, vol. 106, no. 46, pp. 19405-19409, 2009.

[80] S. Perakis, J. J. Matekis, and D. E. Hibbs, "Interactions of tissue and fertilizer nitrogen on decomposition dynamics of ligninrich litter," Ecosphere, vol. 3, no. 6, article 54, 2012.

[81] T. Klotzbücher, K. Kaiser, G. Guggenberger, C. Gatzek, and K. Kalbitz, "A new conceptual model for the fate of lignin in 
decomposing plant litter," Ecology, vol. 95, no. 5, pp. 1052-1062, 2011.

[82] M. M. Coûteaux, K. B. McTiernan, B. Berg, D. Szuberla, P. Dardenne, and P. Bottner, "Chemical composition and carbon mineralisation potential of Scots pine needles at different stages of decomposition," Soil Biology and Biochemistry, vol. 30, no. 5, pp. 583-595, 1998.

[83] J. Perez and T. W. Jeffries, "Roles of manganese and organic acid chelators in regulating lignin degradation and biosynthesis of peroxidases by Phanerochaete chrysosporium," Applied and Environmental Microbiology, vol. 58, no. 8, pp. 2402-2409, 1992.

[84] A. Hatakka, "Biodegradation of lignin," in Biopolymers, Volume 1: Lignin, Humic Substances and Coal, M. Hofman and A. Stein, Eds., pp. 129-180, Wiley, Weinheim, Germany, 2001.

[85] B. Berg, K. T. Steffen, and C. McClaugherty, "Litter decomposition rate is dependent on litter Mn concentrations," Biogeochemistry, vol. 82, no. 1, pp. 29-39, 2007.

[86] B. Berg, "Initial rates and limit values for decomposition of Scots pine and Norway spruce needle litter: a synthesis for Nfertilized forest stands," Canadian Journal of Forest Research, vol. 30, no. 1, pp. 122-135, 2000.

[87] B. Berg, "Decomposition patterns for foliar litter-a theory for influencing factors," manuscript submitted.

[88] J. S. Olson, "Energy storage and the balance of producers and decomposers in ecological systems," Ecology, vol. 44, pp. 322331, 1963.

[89] H. Jenny, S. P. Gessel, and F. T. Bingham, "Comparative study of decomposition rates of organic matter in temperate and tropical regions," Soil Science, vol. 68, pp. 419-432, 1949.

[90] K. T. Steffen, A. Hatakka, and M. Hofrichter, "Degradation of humic acids by the litter-decomposing basidiomycete Collybia dryophila," Applied and Environmental Microbiology, vol. 68, no. 7, pp. 3442-3448, 2002.

[91] K. E. Eriksson, R. A. Blanchette, and P. Ander, Microbial and Enzymatic Degradation of Wood and Wood Components, Springer, Berlin, Germany, 1990.

[92] J. D. Ovington, "The circulation of minerals in plantations of Pinus sylvestris L," Annals of Botany, vol. 23, no. 2, pp. 229-239, 1959.

[93] E. Holmsgaard and C. Bang, "Et traeartsforsøg med nåletraeer, bøg og eg. De Første 10 år," Forstlig Forsøgsvaesen, no. 35, pp. 159-196, 1977 (Danish).

[94] B. Berg, "Sequestration rates for C and $\mathrm{N}$ in humus at four $\mathrm{N}-$ polluted temperate forest stands," in Biogeochemistry of Forested Catchments in a Changing Environment. A German Case Study, E. Matzner, Ed., vol. 172 of Ecological Studies, pp. 361-376, Springer, Berlin, Germany, 2004.

[95] H. Meesenburg, K. J. Meiwes, and H. Bartens, "Veränderung der Elementvorräte im Boden von Buchen- und Fichtenökosystemen in Solling," Berichte Freiburger Forstliche Forschung, vol. 7, pp. 109-114, 1999 (German).

[96] K. J. Meiwes, H. Meesenburg, H. Bartens et al., "Accumulation of humus in the litter layer of forest stands at Solling. Possible causes and significance for the nutrient cycling," Forst und $\mathrm{Holz}$, vol. 13-14, pp. 428-433, 2002 (German), English summary.

[97] C. Akselsson, B. Berg, V. Meentemeyer, and O. Westling, "Carbon sequestration rates in organic layers of boreal and temperate forest soils-Sweden as a case study," Global Ecology and Biogeography, vol. 14, no. 1, pp. 77-84, 2005.

[98] B. Berg, M. Johansson, Á. Nilsson, P. Gundersen, and L. Norell, "Sequestration of carbon in the humus layer of Swedish forests-direct measurements," Canadian Journal of Forest Research, vol. 39, no. 5, pp. 962-975, 2009.

[99] B. Berg, P. Gundersen, C. Akselsson, M. Johansson, Å. Nilsson, and L. Vesterdal, "Carbon sequestration rates in Swedish forest soils-a comparison of three approaches," Silva Fennica, vol. 41, no. 3, pp. 541-558, 2007. 

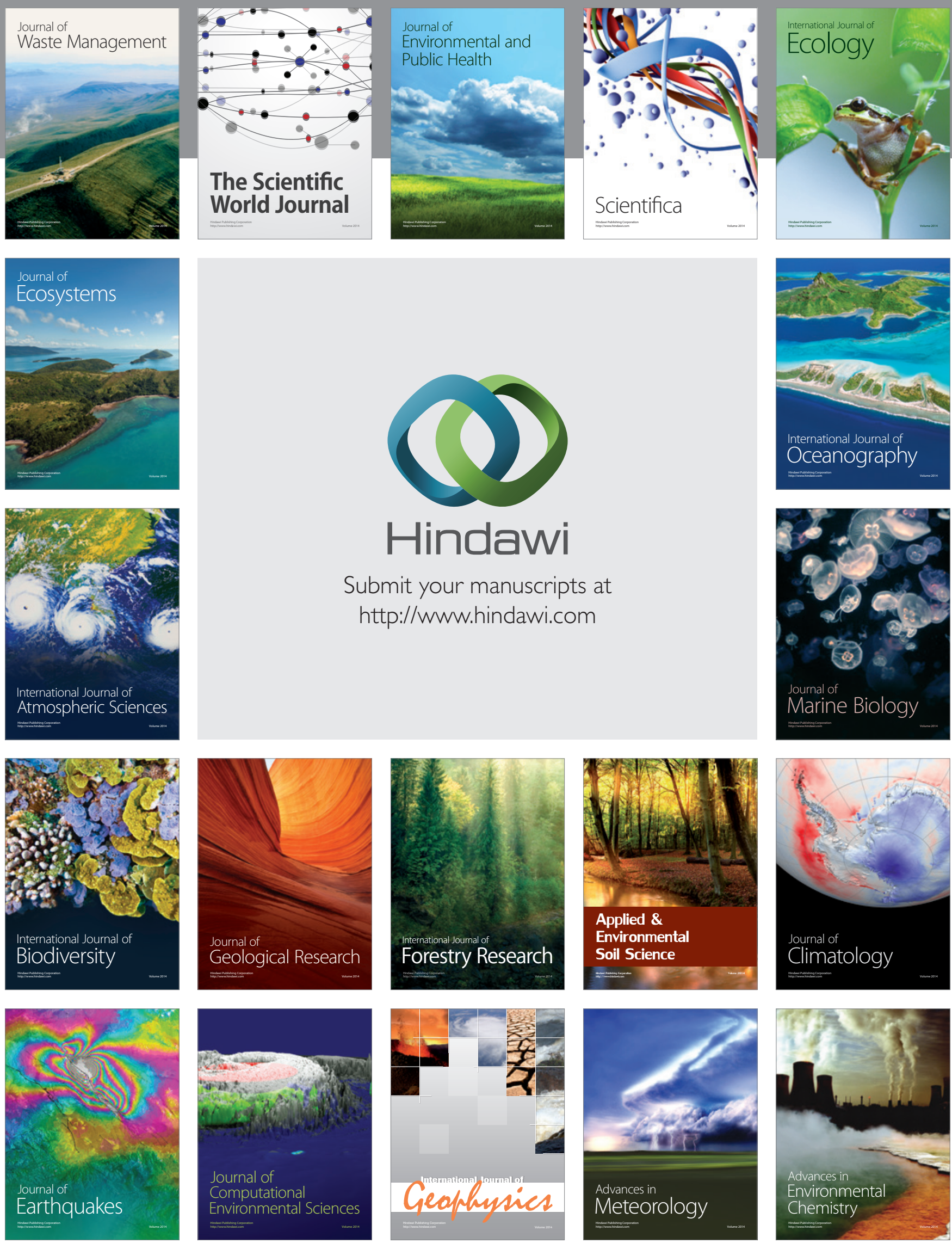